\title{
SOCIAL SCIENCE AND SEGREGATION BEFORE BROWN
}

\author{
HERBERT HOVENKAMP*
}

\begin{abstract}
$A$ wide variety of scholarship has addressed the law of race relations during the late nineteenth and early twentieth centuries. Much of that scholarship has presented the judicial record in the Gilded Age and Progressive Era cases as reactionary and somehow in violation of the basic principles of equality implicit in the American Constitution, particularly in the thirteenth, fourteenth, and fifteenth amendments. Professor Hovenkamp calls this view into question by examining the science and social science of that period and the use of scientific information in race relations cases. He concludes that late nineteenth and early twentieth century courts used prevailing scientific theories in much the same way that the Supreme Court used such theories in Brown v. Board of Education-that judicial decisions of the time were very much a product of the prevailing scientific views concerning the wisdom of separation of the races. Thus, the significant difference between the Progressive Era and the Warren Court lay not in the use of social science, but rather in the content of the science itself.
\end{abstract}

The courts must bear a heavy share of the burden of American racism. An outpouring of recent historical scholarship on racism and the American law reveals the outrageous and humiliating extent to which American lawyers, judges, and legislators created, perpetuated, and defended racist American institutions. ${ }^{1}$ Legal rules recognized and justified

- Associate Professor of Law, University of California, Hastings College of the Law. B.A., Calvin College; J.D., M.A., Ph.D., University of Texas.

1. The following list is only a sampling of the most recent works fitting this description. Others are cited throughout the text. See, e.g., D. Fehrendacher, The Dred ScotT Case: ITS Significance in American Law and Politics (1978) (a study of slavery in America, with a description of the Dred Scott case and an explanation of its political effects); P. FinkelMAN, AN IMPERFECT UNION: SLAVERY, FEDERALISM, AND COMITY 1-19 (1981) (examining "comity" decisions involving the extent to which non-slave states would recognize a slave as property); $\mathbf{M}$. TUSHNET, THE AMERICAN LAW OF SLAVERY, 1810-1860 (1981) (examining pre-Civil War slavery laws from a Marxist perspective). For evidence that both Finkelman and Tushnet overstated their cases, see Nash, In re Radical Interpretations of American Law: The Relation of Law and History, 82 MicH. L. REv. 274, 278-314 (1983) (comparing Finkleman's non-Marxist interpretation of slavery, the Civil War, and related state legislation to the Marxist position provided by Tushnet). Other books on lawmakers' contributions to the institutionalization of American racism and segregation include W. COOPER, LlBerty AND SLAVERY: SOUTHern Politics to 1860 (1983) (examining racial and political attitudes in the South from the colonial period to the Civil War); H. HYMEN \& W. Wiecer, Equal Justice UNDER LAW: CONSTITUTIONAL DEVElopment, 1835-1875, at 55115, 473-517 (1982) (examining the constitutional and legal history of the periods immediately before, during, and after the Civil War, with particular emphasis on the Taney court); L. LITWACK, BEEN IN THE STORM SO LONG (1979) (describing the effect of emancipation on whites and blacks in 
racism. More importantly, legal rules enforced racism by making segregation and the other degradations of racism a legal duty rather than an act of individual free will. ${ }^{2}$ In the process they cleared the consciences of white Americans by relieving them of any sense of responsibility for racist practices.

The law is not autonomous, however, particularly in areas of explicit public policy making. ${ }^{3}$ Lawyers did not invent racism. Rather they created racist institutions because society was racist and racism was implicit im its values. The trend im recent scholarship on the legal history

the South); H. RABinowitz, Race ReLATIONS IN THE URBAN South, 1865-1890 (1978) (discussing black life and the origins of segregation in southern cities during Reconstruction); see generally The Southern EnIgMa: Essays on RaCE, Class and Folk Culture (W. Fraser \& W. Moore ed. 1983); The Ideology of Slavery: Proslavery Thought in the ANTebellum South, 1830-1860 (D. Faust ed. 1981). A good study of black struggles for civil rights in a northeru state during the Civil War is P. Field, The Politics of Race in New York: The Struggle for BLACK SUFFRAGE IN THE CIVIL WAR ERA (1982). The seminal-and perhaps most readable-work on the history of American race relations and the law is R. KLUGER, SiMPLE JUSTICE (1975) (tracing the law of racial segregation throughout the nineteenth century until Brown $v$. Board of Education). A somewhat more optimistic account of the efforts of lawmakers and lawyers in the desegregation effort is C. BARNES, JouRNEY FROM JIM CROW: THE DESEGREGATION OF SOUTHERN TRANSIT (1983) (discussing challenges to segregation in transportation facilities). Important recent articles analyzing segregation cases imclude Riegel, The Persistent Career of Jim Crow: Lower Federal Courts and the "Separate but Equal" Doctrine, 1865-1896, 28 AM. J. LEGAL HIST. 17, 20 (1984) (arguing that historians have overemphasized Plessy and have "largely ignored the development of judicial law legitimizing segregation in the latter third of the nineteenth century"); Schmidt, Juries, Jurisdiction, and Race Discrimination: the Lost Promise of Strauder v. West Virginia, 61 TEx. L. REv. 1401, 1402-05 (1983) (although the Supreme Court under Chief Justice White struck down statutes enforcing residential segregation, peonage, and voting restrictions, it did not question statutes maintaining all-white juries); and the three-part article by Schmidt, Principle and Prejudice: The Supreme Court and Race in the Progressive Era Part I: The Heyday of Jim Crow, 82 Colum. L. REV. 444, 498-524 (1982) (examining and noting criticism of the Supreme Court's decision in Buchanan v. Warley) [hereinafter cited as Jim Crow]; Part 2: The Peonage Cases, 82 Colum. L. REv. 646, 648 (1982) (although the Supreme Court reached the correct result in the Peonage Cases, it did so "in terms of constitutional limitations on legal sanctions for breach of contracts," and not by reflecting on the racial impact of the laws involved); Part 3: Black Disfranchisement from the $K K K$ to the Grandfather Clause, 82 CoLUM. L. REV. 835, $851-70$ (1982) (several southerners, avowed segregationists, presented the government's case for overturning grandfather clauses). The four pieces by Professor Schmidt are a part of his work on volume IX of the Oliver Wendell Holmes Devise History of the Supreme Court of the United States, published as A. Bickel \& B. SCHMIDT, THE JUdICIARY AND RESPONSIBLE GOVERNMENT, 1910-1921 (1984).

2. See, e.g., Berea College v. Kentucky, 211 U.S. 45, 54-58 (1908) (upholding statute that mandated segregated edueation in both public and private schools); Plessy v. Ferguson, 163 U.S. 537, 540-52 (1896) (upholding statute that mandated segregation in intrastate transportation).

3. For a contrary view, which this author found spectacularly unconvincing, sec $M$. TUSHNET, THE AMERICAN LAW OF SLAVERy 28-30 (1981) (legal autonomy is founded upon the self-interested behavior of bureaucrats, the system of legal precedent, and the influence of the ruling class). Tushnet elaborates in Tushnet, Perspectives on the Development of American Law: A Critical Review of Friedman's "A History of American Law," 1977 WIS. L. REV. 81, 102-06 (criticizing the view that "the justices who decided Brown thought that the result was compelled by prior Supreme Court decisions"). 
of American racism, however, has been to place the blame for racism entirely on the lawmakers. C. Vann Woodward began the trend thirty years ago by identifying the rise of the "Strange Career of Jim Crow" with the passage of statutes that mandated segregation in the American South. ${ }^{4}$ Woodward studied both antebellum and post-Civil War America to about 1890 and argued that popular custom favored integration as a general rule, with segregation as the exception. ${ }^{5}$ He suggested that only after southern self-determination was restored at the end of Reconstruction did whites assert their hostility toward blacks. ${ }^{6}$ They did so, argued Woodward, largely through legislation that segregated public facihties, disenfranchised blacks and denied them access to other governmental institutions, and suppressed their economic development. ${ }^{7}$

This article adds needed perspective to the view that the legal profession is responsible for institutionalized racism. The article examines the relationship between law and the social sciences during the period in which many of America's segregationist legal institutions and practices came into effect. The law during this period has often been characterized as "formalistic." 8 Although the term "formalistic" may have many meanings, in this context it refers to a legal system enamored with the imternal consistency of its own rules and generally unconcerned about their effect. ${ }^{9}$ In short, legal formalism is law divorced from policymakmg. Some critics of pre-Realist legal formalism are quick to point out that legal formahism in fact did promote a particular legal policy-the policy of the wealthy and powerful whose values were gradually coming to be represented by a political minority, and who sought to have the law

4. See C. Woodward, The Strange Career of Jim Crow 49-95 (3d ed. 1974) (discussing the wholesale introduction of Jim Crow laws in the 1890's); see also infra notes 76-108 and accompanying text.

5. C. WoODWARD, supra note 4, at 35-47. "In a time when [blacks] . . . formed a much larger proportion of the population than they did later, when slavery was a live memory . . ., and when the memory of the hardships . . . of Reconstruction was still fresh, the Race policies accepted and pursued in the South were sometimes milder than they became later." Id. at 47.

6. Id. at 52 .

7. Id. at $92-95$.

8. See, e.g., K. Llewellyn, The Common law Tradition: Deciding appeals 35-45 (1960) (the "Grand Style" of legal reasoning is preferable to judicial formalism); E. PURCELL, THE Crisis of Democratic Theory: Scientific Naturalism and the Problem of Value 74-76 (1973) (comparing the traditional nineteenth-century method of judicial decisionmaking with the approach of Oliver Wendell Holmes); W. RUMBLE, AMERICAN LEGal REALISM: SKEPTICISM, REFORM, AND THE JUDICIAL PROCESS 49-50 (1968) (describing traditional nineteenth-century legal analysis as "mechanical"); R. SUMMERS, INSTRUMENTALISM AND AMERICAN LEGAL THEORY 137. 60 (1982) (discussing judicial formalism and judicial activism). For a contemporary account, see Pound, Mechanical Jurisprudence, 8 CoLuM. L. REv. 605, 609-23 (1908) (advocating a pragmatic, sociological method of legal analysis).

9. R. SUMMERS, supra note 8 , at 137-40. 
help them achieve what they could no longer achieve at the ballot box..$^{10}$ Legal formalism was a mechanism for disguising this policy-for making a rule such as "liberty of contract" appear to be nonpolitical, although it in fact was a tool designed by its creators to protect themselves from the increasingly powerful labor movement.

The law of race relations in this period contained many faults, but excessive formalism was not prominent among them. In fact, policybased adjudication was as prevalent in the race cases of the Gilded Age and the Progressive Era as in any area of law during that time. However, the policies were different from those espoused by liberal social scientists after the New Deal. According to the prevailing social science of the 1910's and 1920's, the social value created by a comprehensive, stateenforced plan of racial separation was far greater than any costs imposed on its victims. ${ }^{11}$ The thesis of this article is that the law of race relations during this period was a product of the period's social science, just as the law of race relations developed by the Warren Court during the Brown era $^{12}$ was a product of the social science of that period. More importantly, the dramatic revolution in the law of race relations that culminated in the Brown decision was caused by an equally dramatic revolution in American social science. ${ }^{13}$

\section{Segregation, Social Science, and the Brandeis Brief}

No historical legal policy can be evaluated without an understanding of the framework in which the policymakers viewed the world. If members of a society believe a particular scientific theory-for example, that interracial sex produces degenerate children-then they may be willing to sacrifice a great deal to avoid the consequences of interracial marriages. If they later discover that interracial marriages have no such consequences, then they probably will not value avoidance of interracial marriage as highly. In short, people's scientific view of the world determines in large part the social situation that they regard as optimal. The genetic determinism that dominated social science in the last part of the nineteenth century created a situation in which strict racial segregation appeared to be socially prudent. Later, when environmentalism gradu-

10. See, e.g., P. MurPhy, The Constitution IN CRisis Times 1918-1969, at 1-67 (1972) (discussing the laissez-faire economic orientation of the Supreme Court); A. PAUL, ConsERvative CRisis AND THE Rule of LAw: ATTITUdes OF BAR AND BENCH 39-60 (1960) (discussing and noting criticism of several major Supreme Court decisions of the 1890 's).

11. See infra notes $25-63$ and accompanying text.

12. See P. Rosen, The Supreme Court ANd Social Science 134-72 (1972) (examining reactions of the Justices to the use of social science evidence in Brown); see also infra notes 152-78 and accompanying text.

13. See infra notes $222-58$ and accompanying text. 
ally replaced genetic determinism as a theory of race, racial separation became less valuable to society as a whole. ${ }^{14}$ When that happened, certain competing values-such as Americans' more general concern with equality-began to weigh more heavily.

In discussing scientific views of race and the history of the law of race relations, it is useful to distinguish two ways in which courts were influenced by scientific theories. Some scientific or social science data were presented directly to the courts-as in Justice Brandeis's famous brief in Muller $v$. Oregon, ${ }^{15}$ which used social science data to convince the Supreme Court that a state had the constitutional power to regulate the working hours of women even though it could not do so for men. ${ }^{16}$ A second influence, equally important in a judge's decisionmaking, was the "background" scientific information that formed part of a judge's

14. See infra notes $243-58$ and accompanying text.

15. Brief for Defendant in Error, Muller v. Oregon, 208 U.S. 412 (1908), reprinted in 16 LANDMARK BRIEFS AND ARGUMENTS OF THE SUPREME COURT OF THE UNITED STATES: CONSTITUTIONAL LAW 63 (1975). The purpose of the social science brief, or "Brandeis Brief," was to convince the Court that social science data existed that justified the statute at issue and thus would make it pass muster under a test of reasonableness. This kind of evidence was particularly valuable during the era of substantive due process, for in that period the Court determined a statute's constitutionality by inquiring into its substantive reasonableness. The Brandeis Brief distinguishes adjudicative facts, which are established in the court, from legislative facts, data upon which the legislature relied, or could have relied, in drafting its statute. The brief does not assert that the empirical conclusions it recites are true, but only that they are plausible and that a reasonable legislature could have relied upon them in drafting a statute. Brandeis himself made this point in his argument in Stettler v. O'Hara, 243 U.S. 629 (1917), in which the Supreme Court split 4.4 to uphold an Oregon minimum-wage law for women. Argued Brandeis:

In answer to the question, whether this brief contains also all the data opposed to a minimum-wage law, I want to say this: I conceive it to be absolutely immaterial what may be said against such laws. Each one of these statements contained in the brief in support of the contention that this is wise legislation, might upon further investigation be found to be erroneous . . . . [However, t]he question is merely whether . . you can see that the legislators had no ground on which they could, as reasonable men, deem this legislation appropriate to abolish or mitigate the evils believed to exist or apprehended. If you cannot find that, the law must stand.

L. Brandeis, The Curse of Bigness: Miscellaneous Papers $65-66$ (1965 ed.). The Brandeis Brief has been heavily used in constitutional litigation, although until the 1950's the Supreme Court frequently ignored the briefs. See Doro, The Brandeis Brief, 11 VAND. L. REv. 783, $796-99$ (1958) (the Court was generally unswayed by social science arguments after Muller); Karst, Legislative Facts in Constitutional Litigation, 1960 SUP. CT. REv. 75, 100 (discussing successful attempts to use a Brandeis Brief to support the constitutionality of legislation); see also J. JoHNSON, AMERICAN LEGAL CULTURE, 1908-1940, at 30-36 (1981) (further analysis of the Brandeis Brief used in Muller); P. Rosen, THe Supreme Court and Social Science 46-101 (1972) (a more complete historical view of the Brief in constitutional adjudication); 21 C. WRIGHT \& K. Graham, FEDERAL PraCTICE AND PROCEDURE § 5103 (1977) (discussing the problem of using social science data in appellate adjudication today).

16. See Muller v. Oregon, 208 U.S. at 421-22; cf. Lochner v. New York, 198 U.S. 45, 64.65 (1905) (striking down statute that regulated working hours of all bakers). 
perception of the world. ${ }^{17}$ A judge's views about the propriety of statemandated segregation were necessarily a product of both sources of information. Each effected an important yet distinctly different influence on the case law of race relations in the late nineteenth and early twentieth centuries.

In Berea College v. Kentucky, ${ }^{18}$ decided only a few months after Muller v. Oregon, ${ }^{19}$ the United States Supreme Court was for the first time directly and systematically confronted with social science data about race. Its decision in Berea College upheld against constitutional challenge a Kentucky statute inandating statewide school segregation. ${ }^{20}$

Berea College was a church school, an unfortunately-situated product of the fervently evangelical antislavery movement of the 1830's. ${ }^{21}$ Its peculiar geographic setting, in one of the four slaveholding states that remained with the Union during the Civil War, ${ }^{22}$ caused it to experience more difficulty than other small, struggling religious institutions. Berea College entered the post-Reconstruction period as an ideological rarity: a school committed to the integrated education of white and black students, but isolated in a southern, formerly slaveholding state.

Berea College managed to survive local opposition during and after Reconstruction-financial starvation, aggressive racial hostility, and occasional acts of violence against its faculty and students. ${ }^{23}$ It did not fare so well against the new science and politics of the Gilded Age.

Before the turn of the century, a large number of scientific studies warned against the dangers of racial mixing. ${ }^{24}$ Both scientists and laypersons generally believed that Afro-Americans were permanently

17. See R. Horsman, Race and Manifest Destiny: The Origins of American Racial ANGLO-SAXONISM 117-57 (1981) (providing insights into how scientific and pseudo-scientific views about race can infiltrate society's entire cultural perception).

18. 211 U.S. 45 (1908). Other aspects of the case are discussed in A. BICKEL \& B. SCHMIDT, supra note 1 , at $729-32$.

19. 208 U.S. 412 (1908).

20. 211 U.S. 45,58 (1908).

21. For the history of Berea College, see generally E. PECK, BereA's First Century, 18551955 (1955); J. Rogers, Birth of Berea College: A Story of Providence (1904). For discussion of the antebellum reform movement, see S. AHLSTROM, A RELIGIOUS History OF THE AMER1CAN PEOPLE 715-29 (1972) (comprehensive discussion of "traditional" religious history in America, with particular emphasis on the impact of religion on the South during and after the Civil War); $T$. Smith, Revivalism and Social Reform-American Protestanism on the Eve of the CIvil WAR (1965) (arguing that the Protestant ethic is incompatible with slavery).

22. Kentucky, Maryland, Delaware, and Missouri.

23. E. PECK, supra note 21 , at 79-89.

24. See infra notes 152-77. The best discussions of nineteenth century social science and race are found in S. Gould, The MISMEASURe of MAN 20-145 (1981) (discussing and criticizing nineteenth century studies on race). See also H. Cravens, The Triumph of Evolution: AmErican SCIENTISTS AND THE HEREDITY-ENVIRONMENT CONTROVERSY, 1900-1941, at 15-55, 157-265 (1978) (discussing developments in the early twentieth century). 
and inherently inferior, that they learned much more slowly than white persons, and that their close association with whites could contaminate and weaken the white race. ${ }^{25}$ After the Civil War, the possibility of substantial racial mixing became real; the prospect most feared was that of interracial marriage, or "miscegenation."26 Nearly everyone assumed that the way to prevent interracial sexual contact was to keep the races separated, particularly in those institutions where young people's values and attractions were developed, such as the schools. In 1904, therefore, the Kentucky legislature passed a law prohibiting the operation of "any college, school or institution where persons of the white and negro race are both received as pupils for instruction." 27 The statute was aimed directly at Berea-Kentucky's only integrated college. Berea violated the new law, was fined $\$ 1000$, and challenged the constitutionality of the statute. $^{28}$

The college advanced several constitutional arguments, ${ }^{29}$ some of which would be law within twenty years. ${ }^{30}$ Although the fourteenth amendment did not prohibit the state from using its police power to force segregation of public schools, ${ }^{31}$ Berea was a private school. The college asserted that its students had the right to associate with whom they pleased as long as they did not interfere with the rights of outsiders. ${ }^{32}$ Furthermore, because integrated education was an important part of the Bereans' religious beliefs, ${ }^{33}$ Kentucky was interfering with the students' free exercise of that belief. ${ }^{34}$

The Kentucky Court of Appeals rejected all these arguments. It held that the Constitution did not limit the police power of the state to pass segregation laws unless the laws were themselves unreasonable. In this case the Kentucky legislature had done no more than recognize an obvious scientific truth - that " $[t]$ he separation of the human family into races . . . is as certain as anything in nature." 35 Amalgamation of blacks

25. S. Gould, supra note 24 , at 20-145.

26. Id.

27. Act of Mar. 22, 1904, ch. 85, $1904 \mathrm{Ky}$. Acts 181.

28. Berea College v. Kentucky, 211 U.S. 45, 46-50 (1908).

29. Id.

30. See Pierce v. Society of Sisters, 268 U.S. 510, 534-35 (1925) (Oregon's Compulsory Education Act unreasonably interfered with liberties secured by the fourteenth amendment).

31. See Plessy v. Ferguson, 163 U.S. 537, 544 (1896).

32. Berea College v. Commonwealth, 123 Ky. 209, 215, 94 S.w. 623, 624 (1906), affd, 211 U.S. 45 (1908).

33. Berea College, $123 \mathrm{Ky}$. at $215,94 \mathrm{~S} . \mathrm{W}$. at 624.

34. The first amendment arguments were premature, for first amendment rights were not incorporated into the fourteenth amendment and applied to the states until the 1920's. See Gitlow v. New York, 268 U.S. 652, 666 (1925) (due process clause protects freedoms of speech and of the press).

35. Berea College v. Commonwealth, 123 Ky. 209, 221, 94 S.W. 623, 626 (1906), aff'd, 211 U.S. 45 (1908). Kentucky's stated public purpose in passing the statute, as well as other segregation 
and whites was "incoinpatible [with] the continued being of the races" and "repugnant to their instincts." 36 Further, it observed, "[f]rom social amalgamation it is but a step to illicit intercourse, and but another to intermarriage." 37 The state clearly had a right to protect its citizens from the devastating effects of miscegenation. The court admitted that balancing the liberty and pursuit of happiness promised to everyone against the need to preserve racial integrity "forms now one of the biggest questions being worked out by this great North American republic."38 Here, however, the challenged regulation was minimal, and no one's liberty was excessively restricted. No one was denying the freedman's basic right to an education. "[T]o assert separateness is not to declare inferiority in either. . . . It is simply to say that following the order of Divine Providence, human authority ought not to compel these widely separate races to intermix." 39

Berea College also lost in the United States Supreme Court. Justice Brewer limited his analysis to the question of Kentucky's power to control its own private corporations, and never addressed the question of individual rights under the fourteenth amendment. ${ }^{40}$

The most interesting aspect of Berea, however, is not to be found in the Supreme Court's opinion, but in the brief subinitted by the Commonwealth of Kentucky in defense of the segregation statute. James Breathitt, Kentucky's Attorney General, prepared a "Brandeis Brief" somewhat like the one that Brandeis himself had used only three months earlier when he successfully defended the Oregon women's protective statute in Muller v. Oregon. ${ }^{41}$ Breathitt asked the Supreme Court to take judicial notice of certain facts that were not part of the lower court record, but that were "so notorious and universally known as to form a part of the common information of mankind." 42 Then, just as Brandeis had done, the Kentucky Attorney General produced his "scientific" data. The data were not part of the "common information of mankind" at all; in fact, they were quite esoteric and controversial. Breathitt cited an im-

laws, was to preserve race identity, to maintain the purity of blood, and to prevent amalgamation of races. Berea College v. Kentucky, 211 U.S. 45, 51 (1908).

36. Berea College, $123 \mathrm{Ky}$. at 221, 94 S.W. at 626.

37. Id. at $225-26,94$ S.W. at 628 .

38. Id. at $222,94 \mathrm{~S} . \mathrm{W}$. at 626 .

39. Id. at $226,94 \mathrm{~S} . \mathrm{W}$. at 628 .

40. Berea College v. Kentucky, 211 U.S. $45,53-58$ (1908). For contemporary analyses of the decision, generally approving, see Note, Constitutionality of a Statute Compelling the Color Line in Private Schools, 22 HARV. L. REV. 217, 218 (1909) (state's right to prohibit joint education is comparable to state's right to prohibit miscegenation); The Berea College Case, 14 VA. L. REG. 643, 64344 (1908) (praising the Berea College decision).

41. 208 U.S. $412,416,419$ n.1 (1908). See supra note 15.

42. See Brief for Defendant in Error at 40, Berea College v. Kentucky, 211 U.S. 45 (1908). 
portant study by Dr. Sanford B. Hunt, a United States surgeon and pioneer in the field of anthropometrics-the study of the physical characteristics of the races of mankind. ${ }^{43}$ In the 1870's Hunt had discovered that the average Afro-American's brain weighed five ounces less than the average white person's brain. ${ }^{44}$ Actually, almost any nineteenth century anthropologist could have predicted that finding. ${ }^{45}$ Hunt also found, however, that the brain of the average mulatto was even smaller than that of the average black. ${ }^{46}$ Because it was generally assumed that brain weight was directly correlated with intelligence, ${ }^{47}$ Hunt concluded not only that blacks had far less mental capacity than whites, but that intermarriage of the races would produce offspring inferior even to the offspring of "pure-blooded" blacks; ${ }^{48}$ furthermore, these differences among racial types were either permanent or destined to evolve so slowly that it would take thousands of years for blacks to achieve intellectual equality with whites. ${ }^{49}$

Sanford B. Hunt came from a line of American anthropometrists that began with Samuel George Morton, a Philadelphia physician who, in the 1820's, compared the cranial capacities of blacks and whites. Morton's method was simple: he filled each cranium in his collection with white mustard seeds and measured the number it could hold. Morton found differences in cranial capacity that approximated the differences in brain weights Hunt was to discover a half century later. ${ }^{50}$ Morton was also able to obtam the skulls of some 3000-year-old white Egyptians and their black slaves. He performed the same test on these and discovered approximately the same variations in cranial capacity. In three millenia blacks had come no closer to "catching up" with whites. 51

43. Id. at 40-41 (discussing Hunt, The Negro as Soldier, 1 W. J. Psychological MED. 52 (1869)); see J. HALlER, OUTCASTS FROM EVOLUTION: SCIENTIFIC ATTITUDES OF RACIAL INFERIORITY, 1859-1900, at 30-34 (1971) (analysis of Hunt's work).

44. See J. HALLER, supra note 43 , at 33.

45. See S. Gould, supra note 24 , at 20-145.

46. See J. HALLER, supra note 43 , at 33 .

47. See S. GouLD, supra note 24, at 74-111. Other studies found an inverse relationship between brain size and propensity to commit criminal acts. See Hovenkamp, Insanity and Criminal Responsibility in Progressive America, 57 N.D.L. REv. 541, $561-62$ (1981) (discussing studies linking brain size with criminality).

48. Hunt, supra note 43 , at 53-54.

49. Id.

50. See S. Morton, Crania Americana: Or, A Comparative View of the Skulls of Various Aboriginal NATIONS OF North AND South AMERICA 290 (1839). Morton's work was later continued by Josiah Nott and George Gliddon in J. NoTT \& G. GLIDDON, TyPES OF MANKIND (1855). The work of Morton and the reaction to his findings are discussed in W. STANTON, The Leopard's Spots: Scientific AtTitudes Toward RACE IN AMERICA, 1815-1859, at 24-44 (1960) (discussing Morton's background and his views concerning the origin of the races).

51. Morton, Observations on the Size of the Brain in Various Races and Families of Man, 5 Proc. ACad. Nat. Sci. PhiladelphIa 1, 30-33 (1850); see generally S. Morton, Crania Aegyp- 
Attorney General Breathitt argued that this evidence clearly showed that the state had an interest in maintaining racial separation..$^{52}$ The anthropometric studies unambiguously supported the long-held view that there was a substantial "mental gap" between African and Caucasian Americans. Breathitt also argued that the gap "is not the result of education, but is innate and God-given." 53 Science had shown that "education, culture, refinement and civilization [are] the result of the polishing of the inborn and God-given faculty. Training, culture and education never produce faculty. All these are but the growth, the enlargement and expansion of an inborn capacity." 54

Attorney General Breathitt had entered an anthropological battle that had already been hot for a century. What was it that determined racial characteristics - heredity or environment? The theory of evolution by natural selection had greatly changed the nature of the battle when it began to influence anthropology in the 1870's. Far from solving the heredity/environment dispute, however, the theory of evolution made understanding racial characteristics a more difficult task than it had ever been before. ${ }^{55}$

TICA: OR, ObSERVATIONS ON Egyptian EThNography DERIVEd From ANatomy, History AND THE MONUMENTS (1854).

52. Brief for Defendant in Error at 42, Berea College v. Kentucky, 211 U.S. 45 (1908).

53. Id. at 40 .

54. Id. Professor Schmidt dismisses the Kentucky brief as being an extraordinary use of "pseudo-scientific data about racial differences in cranial size, brain weights and the theory of evolution." A. BiCKel \& B. SCHMIDT, supra note 1, at 731 n.10 (1982). However, to regard such data as "pseudo-scientific" merely because it forms part of the scientific world view of a different age is to take an extraordinarily ahistorical view of science. Science is part of our culture, and scientific paradigms are designed by each culture to solve its own problems. Hereditarianism was just as legitimate a scientific view of the world in 1908 as environmentalism is today; and if environmentalism is replaced by a different view, the world view of the 1980's will not thereby become "pseudoscientific." See R. Borger \& F. Cioffi, EXPlanation IN THE BeHAVIoural Sciences 471-515 (1970) (presenting contrary views regarding psychoanalysis as a pseudo-science); see generally $\mathrm{C}$. Gillispie, The Edge of Objectivity (1960); 'T. KuhN, The Structure of Scientific RevoLUTIONS (1962). Today we are inclined to praise Brandeis for his use of social science data in Muller v. Oregon, and to ridicule the scientific racists of the same period. See, e.g., P. Rosen, supra note 12, at 77-87 (favorable explanation of Brandeis's departure from traditional advocacy); R. SUMMERS, supra note 8, at 90 (suggesting that the Brandeis Brief was a novel, but sound, means of presenting extralegal data before the courts). In fact, however, the social science data in the famous Brandeis Brief were designed in part to show that women were inferior to men and thus incapable of entering into their own employment contracts without state regulation. For example, the brief relied on evidence that long working days drove women much more than men to various forms of immorality-most notably vice and alcoholism. Therefore liberty of contract governed contracts in which the employees were male, but not those in which the employees were female. See Brief for Defendant in Error at 44-50, Muller v. Oregon, 208 U.S. 412 (1908).

55. For a general history of the conflict between genetic and environmental determinists in America, see H. CRAVENS, supra note 24 , at 157-90. 
By the time Breathitt argued Berea College in 1908 there were three general positions on the nature of race. The traditional position had long been part of western thought and had become the official view of many American churches, particularly after Charles Darwin published On the Origin of Species in 1859.56 Throughout the last half of the nineteenth century, when great numbers of scientists were anti-evolutionists, the traditional view was also a respected scientific position. This view, quite simply, was that racial characteristics were permanent-"innate and God-given," as Attorney General Breathitt argued.57 God created the species and races "after their kind," and the distinguishing features of each group were a part of its permanent nature. Heredity was the mechanism that ensured this permanence. The rule that "like begets like" was a part of natural law, and any tampering - such as the interbreeding of dissimilar organisins-could have ugly consequences. Although today one can only guess, it is probably safe to say that in 1908 this was the view of racial characteristics adopted by most American non-scientists, and by a substantial minority of scientists as well. As the theory of natural selection became more popular, however, this group of scientists was gradually edged out of the mainstream of the scientific community. ${ }^{58}$

A second group, which included the majority of scientists in 1908, were evolutionists, who placed a great emphasis on the role of genetics in determining racial features. Genetic theory was still being developed at this time, and scientific journals were filled with discussions about the inheritance of physical and mental characteristics. These scientists, led in the social sciences by evolutionary anthropologists Edward Tylor and Lewis Henry Morgan, ${ }^{59}$ believed that characteristics such as intelligence do in fact "evolve," and some of them acknowledged that perhaps someday the Afro-American would develop an intelligence equal to the Caucasian's. However, because the evolution of intelligence is a process that takes thousands of years, the intellectual differences between the races had to be regarded as permanent. ${ }^{60}$ Furthermore, most hereditary deter-

56. C. Darwin, ON the Origin of Species By Means of Natural Selection (1859).

57. Brief for Defendant in Error at 40, Berea College v. Kentucky, 211 U.S. 45 (1908).

58. See P. Carter, The Spiritual Crisis of the Gilded Age (1972) (discussing the postDarwin period); H. HovenKamp, SCIENCE AND Religion IN AMERICA, 1800-1860, at 165-210 (1978) (discussing the pre-Darwin period). The one credible scientific view that the discussion in the text does not mention is polygenesism: the notion that the various races of mankind had separate origins and were genetically distinct species. Those who shared this view abhorred racial mixing even more than the orthodox anti-evolutionists. Several prominent American scientists, such as Harvard University's Louis Agassiz, were polygenesists. By 1908, however, it was no longer a part of mainstream science. See generally H. HovENKAMP, supra, at 165-86; W. STANTON, supra note 50.

59. See infra notes $163-73$ and accompanying text.

60. See infra notes $164-73$ and accompanying text. 
minists argued, race mixing was bad for two reasons. First, it could slow the evolutionary progress of the more advanced race. Second, when organisms with dissimilar genes interbreed, this increases the possibility of producing bizarre, unhealthy offspring-offspring with disproportioned features, mental deficiency, weakness, and disease. ${ }^{61}$

On two matters, these groups generally agreed. First, they believed that integrated education was bad because blacks learned much more slowly than whites. The presence of black children in a classroom would therefore retard the progress of the white children. Second, they believed that social integration of any kind was bad because race inixing would eventually lead to miscegenation. ${ }^{62}$ As the Kentucky Court of Appeals said, "[f]rom social amalgamation it is but a step to illicit intercourse, and but another to intermarriage." 63

A third view of racial differences was held by a small number of scientists who, in 1908, liad barely begun to make themselves heard. Members of this group-the environmentalists-were not to have a significant impact for almost a generation, ${ }^{64}$ and their views inay have been altogether unknown to Attorney General Breathitt. These scientists were themselves evolutionists, and they agreed with the genetic determinists that some human characteristics were hereditary and would take a long tinie to change by evolution-for example, skin color, facial features, or physical size. The environmentalists, however, believed that other characteristics-such as behavior and intelligence-are deternined largely by the outside influences that affect an individual during his developniental period. ${ }^{65}$ Thus the only true intellectual difference between blacks and whites was that blacks had not had the advantage of the white person's life situation, economic status, or education. More importantly, the genetic differences between the races were not nearly as great as the genetic determinists believed;66 rather, racial differences were subvarietal. If one plotted all the world's organisnis on a chart, the different races of liumanity would be so close together that they would appear to be one. Because people are people, they perceive hunian racial differences as being quite large. Yet most laypersons could not even distinguish two sub-

61. See infra notes $172-73$ and accompanying text.

62. See H. Cravens, supra note 24 , at $157-90$ (tracing the rise of racial determinism); $M$. Harris, The Rise of ANTHRopological Theory 80-107 (1968) (same).

63. Berea College v. Commonwealth, $123 \mathrm{Ky} .209,222,94$ S.W. 623, 626 (1906), affd, 211 U.S. 45 (1908).

64. See generally H. CRAvENS, supra note 24 , at 157-90.

65. Id.

66. Perhaps the earliest statement of this view is Haldeman, Enumeration of Recent FreshWater Mollusea, 4 B.J. NAT. HIST. 468, 481-84 (1844). These ideas are also present in the work of Franz Boas and Melville Herskovits. See infra notes 239-50 and accompanying text. 
varieties of rabbits or mollusks. The environmentalists thus argued that, notwithstanding any negative social consequences, racial interbreeding would probably have no harmful biological consequences. ${ }^{67}$

By 1908 the people in the first of these three groups-the religious anti-evolutionists-had produced an immense literature on the nature of racial characteristics, the "mental gap" between blacks and whites, and the dangers of racial mixing. ${ }^{68}$ Most of this literature was aimed at a lay audience, but the arguments relied heavily on contemporary science. Frequently the scientific and religious arguments were so closely intertwined that it was hard to tell where one ended and the other began. ${ }^{69}$

The hereditary determinists in the second group had also produced a large amount of hiterature, most of it fairly learned and technical. ${ }^{70}$ Attorney General Breathitt, however, was not a scientist; his perspective on the race problem came largely from popularizers, most of whom were quite religious and antagonistic toward the theory of evolution.

In his brief, Breathitt ended his scientific argument proving that racial mixmg was bad social policy by quoting an "eminent writer on natural selection."71 The writer, it turned out, nray have been eminent-but as a nrathematician, not a naturalist. He was William Benjamin Smith, a German-educated professor at Tulane University. Around the turn of the century Smith had becone interested in heredity-particularly in "eugenics," the social control of procreation to improve the quality of the human race. ${ }^{72}$ In 1905 Snith published a popular book called The Color Line, which summarized the current anthropological and sociological information about the abilities and linitations of the Afro-American..$^{73}$ James Breathitt's brief quoted from Smith's conclusions:

[T] he notion of social racial equality is . . . abhorrent alike to instinct and to reason. It is idle to talk of education and civilization and the like, as corrective or compensative agencies. All are weak and beggarly as over against the almightiness of heredity; the omnipotence of the transmitted germ plasma." 74

Attorney General Breathitt did not address the scientific basis for Snith's conclusions. Rather, he relied on the mutual support that the

67. See infra notes $243-52$ and accompanying text.

68. See R. HorSman, supra note 17, at 139-57 (discussing the dissemination of scicntific racialism in America).

69. Id. at $139-40$.

70. See supra notes 59-61 and accompanying text; see generally D. PICKENS, EUGENICS AND THE Progressives 182-201 (1968).

71. Brief for Defendant in Error at 41, Berea College v. Kentucky, 211 U.S. 45 (1908).

72. See D. P1CKENS, supra note 70, at 182-201 (discussing the eugenics movement).

73. W. SMITH, The COLOR LINE: A BRIEF IN BEHALF OF THE UNBORN 81 (1905).

74. Brief for Defendant in Error at 41, Berca College v. Kentucky, 211 U.S. 45 (1908) (quoting W. SMrTh, supra note 73 , at 81 ). 
hereditary theory of racial intelligence and the long-held values of American Christian orthodoxy appeared to provide for each other. To say that the mental capacity of the Afro-American was "inborn" and to say that it was "God-given" were the saine thing. Both Smith and Breathitt believed that racial types were the product of divine creation, not of gradual adaptation to a changing environment. ${ }^{75} \mathrm{By}$ using the scientific data he found, Breathitt could show that science was confirming what theologians and the courts had known for a long time: people were as God made thein, and no amount of social engineering could change them.

\section{The Myth of Our Integrated Past}

\section{A. Legalized Exclusion Before the Era of "Jim Crow."}

The "science" on which Breathitt relied in his Berea College brief simply reflected the values of the times. In 1908 the notion that black and white students could be educated in the same classrooms was repulsive to the great inajority of white Americans-northerners and southerners alike. In general, the idea that blacks and whites should share any kind of public facility made white Americans in every part of the country uncomfortable. One of the inyths of American history is that at the time of the Civil War northern whites wanted to promote social integration, while southern whites wanted to avoid it.

A popular theory - one most recently advanced by Professor Benno Schmidt-is that "Jim Crow" segregation in the post-war Soutl was really a product of the late nineteenth century. ${ }^{76}$ According to this theory, there was really no need for segregation before the Civil War because slavery created a caste system in which every black person knew his place. The relatively few blacks who were free posed no threat to white institutions, and whites were not sufficiently bothered by their presence to atteinpt comprehensive segregation. ${ }^{77}$ Slaves generally accompanied their masters everywhere. During Reconstruction, lowever, the South

75. Brief for Defendant in Error at 40-41, Berea College v. Kentucky, 211 U.S. 45 (1908).

76. See A. BICKEL \& B. SCHMIDT, supra note 1, at 746-66. The best example of the "Jim Crow" theory is C. WOODWARD, supra note 4, at 13-14, an immensely influential and popular book that has had a strange career of its own. Professor Woodward revised it several times to account for new data that forced modification of the original Jim Crow thesis. See C. Woopward, Origins of THE NEW SOUTH, 1877-1913, at 211-12 (1957) (noting that no state enacted a Jim Crow law for more than twenty years after the Civil War and arguing that the barriers of racial discrimination mounted as whites in the South attained political democracy during the latter decades of the nineteenth century); see also R. KLUGER, supra note 1, at 51-74. The controversy over Woodward's original "Jim Crow" thesis is summarized in Riegel, supra note 1, at 19 (although legal historians in particular have been faithful to Woodward's original thesis, others have contended that de facto segregation pervaded the South immediately after the Civil War).

77. C. WOODWARD, supra note 4, at 14. 
became occupied territory on which a set of foreign-northern-racial values was imposed. ${ }^{78}$ The Radical Republicans, who dominated the federal government and controlled southern legislation, tried to establish black pohtical equality and social integration as a new southern way of life. Not until the 1880's, when southern federalism had been restored, did the offended and threatened southern whites inaugurate the era of Jim Crow to ensure that whites retained their dominant social position and that blacks once again became aware of their place in society. ${ }^{79}$

The Jim Crow theory, however, does not accord with some of the facts. ${ }^{80}$ In debatimg whether the antebellum and Reconstruction South practiced segregation or imtegration, many historians neglected the fact that the social practices of the day mcluded a third and widely practiced alternative: exclusion. "Separate but equal" statutes such as the one at issue in Plessy v. Ferguson ${ }^{81}$ did not always abrogate de jure integration that had been imposed by Reconstruction governments, or de facto integration that had always been part of the southern way of life. Often such statutes replaced laws or customs that allowed blacks no accommodations at all. ${ }^{82}$

Before the Civil War most southern schools, hospitals, asylums, hotels, restaurants, and other public facilities excluded blacks. ${ }^{83}$ Many

78. Id. at 5.

79. Id. at 6-9.

80. The best attacks on the myth are D. FeHrenbacher, The Dred SCoTt CASE 580-82 (1978) (resistance to Reconstruction was based as much on traditional federalism as on racism); W. GILlETTE, RETREAT FROM RECONSTRUCTION, 1869-1879, at 186-235 (1979) (examining debates over racial equality after 1892); H. RABINOWITZ, RACE RELATIONS IN THE URBAN SOUTH: 18651890, at 259-81 (1978) (racial policies during Reconstruction were shaped by local Democrats' struggles with Republican appointees).

81. 163 U.S. 537 (1896).

82. Professor Schmidt, in Jim Crow, supra note 1, at 461-64, adopts the Vann Woodward "Jim Crow" thesis without considering the alternative offered by Professor Rabinowitz. Thus, for example, Professor Schmidt describes the Plessy v. Ferguson era as one in which "the Court turned away from the constitutional claims of Reconstruction." Id. at 461. Implicit in Schmidt's argument is the premise that the "claims of Reconstruction" included integration, and that the Supreme Court's decision in Plessy ignored that constitutional history. In fact, there is no plausible argument that either the 1866 Congress that drafted the fourteenth amendment or the Congress that passed the 1875 Civil Rights Act had such integration in mind. See infra notes 106-42 and accompanying text.

83. See H. RABINowitz, supra note 80 , at $182-83$ (until the 1870 's, exclusion rather than segregation was used to separate the races); see also Rabinowitz, From Exclusion to Segregation: Southern Race Relations, 1865-1890, 63 J. AM. HIsT. 325, 325-27 (1976) (blacks were excluded from sehools, hospitals, asylums, and public accommodations prior to the Civil War). Rabinowitz and Woodward differ in their conclusions probably because each author used different source materials. Woodward based his work largely on the development of statutory law and on New Deal studies of American race relations. See C. WooDWARD, supra note 4, at 49-95. Rabinowitz additionally looked at many primary sources of social history: newspapers, letters, and other descriptive writing. See H. RABINowITZ, supra note 80, at 182-97. Few historians have made use of a third set of invaluable sources: the records of the hundreds of race cases that were litigated in various state and federal courts. For 
southern states had no public school systems, and education was provided only at privately endowed institutions. ${ }^{84}$ Slave states generally made it illegal for enslaved blacks to go to school at all. ${ }^{85}$ North Carolina had the only statewide antebellum public school system, but it was open only to whites. ${ }^{86}$ Georgia, Arkansas, and Texas all established public schools during the early years of Reconstruction, while tliey were controlled by Reconstruction legislatures; these systems were segregated by statute. ${ }^{87}$ Tennessee was firmly in the liands of Radical Republicans when it established its public scliool system in $1866 .{ }^{88}$ The Tennessee system provided for the education of black children, but on a segregated basis. ${ }^{89}$ During the late 1860's and early 1870's, when Reconstruction was firnly estabhished, soutliern public scliool systems were forced to educate blacks. With the exceptions of South Carolina and Louisiana, however, all these southern systems placed black children and white cliildren in separate schools. ${ }^{90}$ Likewise, most public places of amusement were operated exclusively for members of one race during these years. The newspapers of Reconstruction Atlanta, Nashville, and Montgomery were filled with advertisements for "Negro barrooms," "Negro billiard parlors," or "colored skating rinks." New Orleans and Nashville mamtained segregated racetracks, Montgomery operated racially exclusive parks, and most privately owned theatres were segregated, with blacks permitted to sit only in designated sections of the galleries. ${ }^{91}$

example, the trial transcript of DeCuir v. Benson, 27 La. Ann. 1 (1875), part of which appears in the record of Hall v. DeCuir, 95 U.S. 485 (1877), contains a wealth of information about the racial policies of privately owned steamships both before and after the Civil War. See also Fischer, $A$ Pioneer Protest: The New Orleans Street Car Controversy of 1867, 53 J. NEGRo HIST. 219, 219-20 (1968) (some streetcar lines excluded blacks altogether prior to the 1862 Union occupation).

84. See H. RabiNowiTZ, supra note 80 , at 162-64 ("[O]nly North Carolina made any signifcant antebellum progress in . . public education.").

85. See D. FeHrenbacher, The Dred SCott CASE: Its Significance in AMERICAN LAw AND Politics 35 (1978) (discussing penalties for teaching slaves to read and write); H. RABINOwITZ, supra note 80 , at 152 ("[L]aws prohibited slaves from receiving an education.").

86. H. RABINOWITZ, supra note 80, at 162-64.

87. See An Act to Establish a System of Public Instruction, Pub. L. No. 53, 1870 Ga. Laws 49, 57; An Act to Establish and Maintain a System of Free Common Schools for the State of Arkansas, No. LII, $\S 107,1868$ Ark. Acts 163, 196; An Act to Establish a System of Public Free Schools for the State of Texas, ch. LXVIII, § 3(7), 1870 Tex. Gen. Laws 113, 114. The 1876 Texas Constitution, written immediately after Reconstruction, made segregated public education mandatory. TEX. CONST. of 1876, art. VII, $\S 7$; see also Act of Aug. 11, 1868, 1868 Ala. Acts 148 (making segregation in public schools inandatory unless all parents consented to integration); Act of Apr. 12, 1869, ch. $184, \S 50,1868-69$ N.C. Pub. Laws 458, 471 (requiring separate schools for children of each race).

88. See J. Cartwright, The Triumph of Jim Crow: Tennessee Race Relations in the 1880 's, at 7-13 (1976).

89. Act of Mar. 5, 1867, ch. XXVII, § 17, 1866-67 Tenn. Pub. Acts 33, 39-40.

90. See Brief for Appellees on Reargument at 31, app. B at 22-23, app. C at 8-18, Briggs v. Elliott, consolidated with Brown v. Board of Educ., 347 U.S. 483 (1954).

91. See H. RABINowrTz, supra note 80 , at $182-91$. 
The situation was similar with respect to public transportation. Since before the War, Nashville had operated a street railway system that excluded blacks; in 1867, however, it began to operate separate cars for blacks. ${ }^{92}$ Likewise, in New Orleans, the operation of separate but equal streetcars replaced a custom of complete exclusion that probably predated the Civil War. ${ }^{93}$

Interstate railroads and steamboats on navigable waters were regulated by federal law, which prohibited them from refusing passage to any paying customer. ${ }^{94}$ However, long before the War and also during the height of Reconstruction, river steamboats maintained policies of fairly strict segregation. In 1869 Louisiana's Reconstruction legislature passed a statute prohibiting common carriers from making any "discrimination on account of race or color"9s in accepting passengers. The law did not clearly specify whether carriers had to integrate passengers or whether they could furnish them separate, equivalent accommodations.

When the constitutionality of the Louisiana statute was challenged im $1875,{ }^{96}$ the defendant steamboat operator called a number of witnesses who testified about the practices in the steamboat passenger business. Thomas P. Leathers, who had been steamboating for thirty-six years, testified that the practice was to have a "colored cabin" separate from the accommodations for whites. ${ }^{97}$ "This regulation and custom among steamboats . . of keeping the white and colored passengers separate, has prevailed ever since I have been steamboating; I have never heard of any other."98 Several other witnesses gave similar testimony. ${ }^{99}$

In 1870 the Georgia legislature, completely controlled by Reconstruction Radical Republicans, ${ }^{100}$ passed a separate-but-equal statute that mandated segregation in privately-owned public facilities. ${ }^{101}$ In

92. Rabinowitz, supra note 83 , at 327 ; see generally C. BARNES, supra note 1.

93. See Fischer, supra note 83, at 219-20, 232 (de jure segregation imposed in 1902, after preCivil War exclusion and post-Civil War de facto segregation).

94. See Pearson v. Duane, 71 U.S. (4 Wall.) 605, 615 (1866) (admiralty libel case); Brown v. Memphis \& C.R. Co., 5 F. 499, 502 (C.C.W.D. Tenn. 1880) (exclusion from the ladies' car of allegedly unchaste woman violated the commerce clause).

95. Act of Feb. 23, 1869, No. 38, § 1, 1869 La. Acts 37, 37.

96. Hall v. DeCuir, 95 U.S. 485 (1877); DeCuir v. Benson, 27 La. Ann. 1, 2 (1875).

97. DeCuir v. Benson, 27 La. Ann. 1, 9 (1875).

98. Id.

99. Record at 9, Hail v. DeCuir, 95 U.S. 485 (1877). The record contains about 35 pages of testimony describing the segregation practices in the steamship industry. All the witnesses testified that segregation was the rule of the day and that no operator who attempted integration could have remained in business. Id. The testimony was uncontradicted.

100. Id.

101. Act of Oct. 18, 1870, Pub. L. No. 258, 1870 Ga. Laws 398 (mandating separate but equal accomodations). 
1881 Tennessee, which still had a Republican governor, followed suit. ${ }^{102}$ Even the Civil Rights Act of 1875, ${ }^{103}$ which remained in effect in $1881,{ }^{104}$ did not dissuade southern states from passing segregation statutes. ${ }^{105}$

It is perplexing that states controlled by Union-imposed Radical Republican governments would pass such segregation statutes, particularly in view of the fact that the Civil Rights Act of 1875 appeared to prohibit the racial discrimination that these state statutes mandated. 106 One possible explanation is that these Radical Republican legislatures believed that the federal Civil Rights Act would be declared unconstitutional, as it eventually was in $1883 .{ }^{107}$ That, however, would not explain their motive for segregation-after all, the Civil Rights Act of 1875 was itself a product of the Radical Republican Reconstruction movement.

In fact, the Radical Republicans did not want racial integration any more than southern whites did. Furthermore, they did not believe that the Civil Rights Act of 1875 mandated racial integration. The notion advanced by Professor Schmidt-that the 1875 Civil Rights Act was an "integration" statute108 -is the product of a century of hindsight: we have effectively read our post-Brown values into a statute that never contained them.

The Civil Rights Act of 1875 made it a crime for any person to deny another the "full and equal enjoyment of the accommodations, advantages, facilities, and privileges" of public facilities. ${ }^{109}$ According to the reasoning the Supreme Court adopted in Plessy v. Ferguson ${ }^{110}$ in 1896, separate but equal facilities did in fact give blacks the "full and equal

102. See H. Rabinowitz, supra note 80, at 185; Folmsbee, The Origin of the First "Jim Crow" Law, 15 J. S. Hist. 235 (1949) (discussing circumstances surrounding passage of the Tennessee law).

103. Civil Rights Act of 1875, ch. 114, 18 Stat. 335.

104. The 1875 Civil Rights Act was declared unconstitutional by the Supreme Court in The Civil Rights Cases, 109 U.S. 3, 25 (1883).

105. See Rabinowitz, supra note 83 , at $333-34$ (southern states were only marginally bothered by the Civil Rights Act prior to its demise); see also W. GilletTe, Retreat From ReconstrucTION, 1869-1879, at 186-235 (1979) (discussing Reconstruction Republicans' lack of commitment to racial equality).

106. Civil Rights Act of 1875 , ch. $114, \S 1,18$ Stat. 335, 335-36. The statute provided:

That all persons within the jurisdiction of the United States shall be entitled to the full and equal enjoyment of the accommodations, advantages, facilities, and privileges of inns, public conveyances on land or water, theatres, and other places of public amusement; subject only to the conditions and limitations established by law, and applicable alike to citizens of every race and color, regardless of any previous condition of servitude.

Id. The second section created a private eause of action for violations. Id. $\$ 2,18$ Stat. at 336 .

107. The Civil Rights Cases, 109 U.S. 3, 25 (1883).

108. See A. BICKEL \& B. ScHMIDT, supra note 1, at 746 (reading the Civil Rights Act of 1875 as prohibiting segregation).

109. Civil Rights Act of 1875 , ch. $114, \S 1,18$ Stat. 335, 335-36.

110. 163 U.S. 537 (1896). 
enjoyment" of public facilities. ${ }^{111}$ It is not entirely clear what the federal government and southerners understood the 1875 statute to require. However, the Civil Rights Cases, ${ }^{112}$ in which the Supreme Court held the Act unconstitutional in 1883, were not segregation cases at all. The Supreme Court heard arguments in four criminal cases and one civil case. ${ }^{113}$ Each of these involved either the absolute exclusion of blacks from the facility, or the provision of facilities that were not "equal." 114 The record in the case involving a railroad shows, for example, that the defendant railroad company did not operate "separate but equal" cars for blacks, but consistently relegated them to the dirty, unsanitary, and grossly inferior "smoking" cars. 115 That would have been a violation of the federal statute no matter how it was construed.116

The Supreme Court in the Civil Rights Cases never reached the issue of separate but equal accommodations. It found the Act unconstitutional on the grounds that the fourteenth amendment authorized Congress to protect only against state action, not against the racial policies of privately owned businesses. ${ }^{117}$

\section{B. "Political" and "Social" Equality.}

The Civil War Amendments and the Civil Rights Act of 1875 were designed to give blacks "equal" access to certain institutions and facilities-but in 1875 equal access did not mean integrated access. The "sep-

111. Id. at 551 .

112. 109 U.S. 3 (1883); see Gressman, The Unhappy History of Civil Rights Legislation, 50 Mich. L. REv. 1323, 1340-43 (1952) (discussion of the practical effect of these cases).

113. The Civil Rights Cases, 109 U.S. at 4-5.

114. One case involved an indictment against a San Francisco theater operator for refusing to seat a black man in the orchestra area or dress circle. When the complainant presented his ticket for that area the attendant denied him admission to any part of the theater. The Civil Rights Cases, 109 U.S. 3, 4 (1883). Another involved the denial of full accommodations by a New York opera house. Id. Two of the cases were convictions of restaurant or inn owners who had refused to admit blacks. Id. In the fifth case, a black woman had bought and paid for a first class train ticket but had been refused admission to the ladies' car. The woman brought a civil action against the railroad. Id. at 5 . In the railroad case the petitions made a great deal of the fact that the alternative seating offered the complainants was dirty, unsanitary, and grossly inferior to the first class accommodations for which they had paid. See id. at 7 . Such allegations would have been unnecessary if the federal statute had prohibited a simple refusal to integrate.

115. See id. at 7-10. The brief filed by the United States in defense of the statute is cast entirely in terms of exclusion/inclusion, not segregation/integration. See, e.g., Brief of the United States at 1-2, The Civil Rights Cases, 109 U.S. 3 (1883) ("The cases of Stanley and Nichols present indictments for refusing to admit colored persons into inns; that of Ryan is an information for refusing to admit a colored person to the parquette of a theater, and that of Hamilton-an indictment for excluding a colored person from the first-class cars of a railroad train.") (emphasis deleted); see also id. at 17 ("I submit, therefore, that . . . the right to use an inn or a train of cars . . . is one of the rights of locomotion, and therefore a high constitutional right.").

116. See supra notes 106, 109-11 and accompanying text.

117. The Civil Rights Cases, 109 U.S. at 11, 25-26. 
arate but equal" decisions that seem so clearly today to violate the spirit of the equal protection clause did not appear to do so during the Gilded Age. In fact, the outcome in Plessy v. Ferguson would have been the same even if the Civil Rights Act of 1875 had been upheld by the Supreme Court. Northerners and southerners alike feared the consequences of close racial mixing, and few people in any part of the country would liave been prepared for a rule that forced blacks and whites to share integrated public facilities. ${ }^{118}$

The reported opimions of the lower federal courts support this conclusion. Generally, even Radical Republican federal judges blanched at any notion that the 1875 Act inandated racial integration. A inonth after the statute was passed federal Judge Robert P. Dick, an anti-secessionist who had joined the Radical Republicans, explained the new statute to a North Carolina grand jury. The law, he said, merely declared what was already the common law of North Carolina-that an innkeeper inust accept every paying customer regardless of his color. ${ }^{119}$ However, in doing this the innkeeper "Inay arrange his business to suit lis own advantage," and the guest has "no right to select a particular apartment."120 According to Judge Dick, the new Federal Civil Rights Act was not "intended

118. See generally McPherson, Abolitionists and the Civil Rights Act of 1875, 52 J. AM. HisT. 493, 509 (1965) (examining public reaction to the 1875 Civil Rights Act).

119. Charge to Grand Jury-The Civil Rights Act, 30 F. Cas. 999, 1000 (C.C.W.D.N.C. 1875) (No. 18,258); see Avins, The Civil Rights Act of 1875: Some Reflected Light on the Fourteenth Amendment and Public Accommodations, 66 CoLuM. L. REv. 873, 876-915 (1966) (discussing the problem of determining Congressional intent); Wyatt-Brown, The Civil Rights Act of 1875, $18 \mathrm{~W}$. PoL. Q. 763, 769-74 (1965) (same). Avins and Wyatt-Brown do not discuss the issue of separate but equal accommodations. The thesis that Congress passed the 1875 Act with complete integration in mind is undermined by the fact that it provided for segregated public schools in Washington, D.C., in 1866, Act of July 23, 1866, ch. 217, 14 Stat. 216, and again in 1873, Act of Mar. 3, 1873, ch. 308, 17 Stat. 619, 619-20. The segregation practiced in the District of Columbia school system is enlightening because the system was being run by Congress when both the fourteenth amendment and the Civil War Civil Rights Acts were passed. See Brief for Respondents at 12-13, Bolling v. Sharpe, 347 U.S. 497 (1954) (history of school segregation in Washington, D.C.). For a contrary view of congressional intent, see Note, Is Racial Segregation Consistent with Equal Protection of the Laws? Plessy v. Ferguson Reexamined, 49 ColuM. L. Rev. 629, 631-33 (1949) (interpreting newspaper reports and legislative history of the fourteenth amendment and concluding that it was intended to prohibit segregation).

Judge Dick's conclusion that the 1875 Act merely declared the law of North Carolina is rather peculiar. The Act permitted parties to proceed "under their rights at common law and by state statutes"-that is, it did not preempt consistent state law. The Civil Rights Act of 1875, ch. 114, $\S 2,18$ Stat. 335,336 . There is, however, no basis for thinking that it simply declared the law of each state.

120. Charge to Grand Jury-The Civil Rights Act, 30 F. Cas. 999, 999 (C.C.W.D.N.C. 1875) (No. 18,258). 
to confer any rights or privileges of social equality among men."121 The judge concluded that the new statute "only proposes to provide for the enforcement of legal rights guaranteed to all citizens by the laws of the land, and leaves social rights and privileges to be regulated, as they have been, by the customs and usages of society."122 Under this rationale Judge Dick held that "innkeepers may have separate rooms and accommodations for colored men, but they must be equal in quality and convenience to those furnished white men. [Likewise, r]ailroad companies may have first class coaches for colored men, and first class coaches for white men." 123

Four years after the statute was passed, a federal court in Georgia dismissed the claim of a black woman who had been forced by a steamship conductor to accept accommodations in the colored section on the lower deck. District Judge John Erskine, another anti-secession Johnson appointee, made short work of her complaint:

Congress has not deemed it necessary or essential . . . to enact any law forbidding inter-state common carriers [from providing] accommodations for colored passengers [that] may be distinct and separate from those assigned to white passengers. [However,] colored passengers are entitled to accommodations as suitable as those designated for the exclusive use of white passengers. ${ }^{124}$

Incredibly, Judge Erskine never even mentioned the 1875 Civil Rights Act, even though the statute explicitly covered "public conveyances on land or water."125 It is highly unlikely that Judge Erskine did not know about the Act. ${ }^{126}$ A more plausible explanation is that it was obvious to

121. Id. at 1000 . After all, the judge continued, "the hope and expectation that there will ever be a nation on earth in which all men associate upon terms of social equality is a wild dream of fanaticism, which can never be realized." Id. at 1000-01.

122. Id. at 1001 .

123. Id.

124. Green v. City of Bridgeton, 10 F. Cas. 1090, 1093 (S.D. Ga. 1879) (No. 5754).

125. Civil Rights Act of 1875, ch. 114, § 1, 18 Stat. 335, 336.

126. The United States Supreme Court's decision in Hall v. DeCuir, 95 U.S. 485 (1878), may explain Judge Erskine's failure to discuss the 1875 Civil Rights Act. In July 1872 DeCuir had boarded an interstate steamship and was refused admission to the "whites only" cabin. The Act had not been passed, but DeCuir sued under the Louisiana Civil Rights Act of 1869. Id. at 486. The Supreme Court declared the Louisiana statute an unconstitutional state regulation of interstate commerce and never reached the "separate but equal" issue. Id. at 490-91. In a concurring opinion, Justice Clifford discussed both the Federal Civil Rights statute, which had been passed while the case was in litigation, and the Civil War Amendments. Id. at 508-09. Clifford believed that neither the statute nor the amendments had been intended to supersede the large body of federal law regulating transportation on navigable waters. Under that law interstate carriers could not turn away any paying passenger, regardless of race, but separate accommodations had always been the rule. Id. at 509. The language of the 1875 Act somewhat ambiguously supports Justice Clifford, for the Act makes its provisions "subject only to the conditions and limitations established by law." Civil Rights Act of 1875 , ch. 114, $\$ 1,18$ Stat. 335, 336. Because there was already a body of federal law regarding treatment of blacks aboard interstate steamships, Justice Clifford apparently presumed that the 
him that the statute was not intended to prevent common carriers from providing separate, equivalent accommodations. The judge ruled that the black section of the ship offered substantially the same accommodations as the white section and dismissed the complaint. ${ }^{127}$

No federal judge, Radical Republican or otherwise, interpreted the 1875 Civil Rights Act to require the integration of public facilities. ${ }^{128}$ The social costs of such an imposition were too high. In fact, given the scientific world view of the 1870 's, those costs were perceived as so high that no one even took seriously the argument that the Act demanded the full mtegration of such public facilities as steamboats, trains, or movie theatres.

The same conclusion apphies to the equal protection clause of the fourteenth amendment. The intent of the framers of the fourteenth amendment has been debated frequently, particularly in the wake of

Act was inapplicable to such vessels. Nevertheless, when Judge Erskine wrote his opinion, no court had so held. Further, it is unlikely that Congress intended such an exemption; the Act made explicit reference to "public conveyances on land or water." Id.

Several other federal decisions construed the 1875 Act. See United States v. Dodge, 25 F. Cas. 882, 883 (W.D. Tex. 1877) (No. 14,976) (charging jury that the federal statute prohibited railroads from discriminating with respect to race, but that the jury should acquit if it found that the railroad maintained racially exclusive cars that were "in all respects, equal"); see also Gray v. Cincinnati S. Ry., 11 F. 683, 686 (C.C.S.D. Ohio 1882) (requiring equality, but not integration, of accommodations on railroad cars).

Chief Justice Warren's conclusion in Brown v. Board of Education, 347 U.S. 483 (1954), that segregated schools were "inherently unequal," id. at 495 , was the product of six or seven decades of hindsight. Although the judges of the Gilded Age did not have the benefit of that hindsight, the jury charge in Gray reveals that even after seven years of litigation under the Civil Rights Act, the "separate but equal" question had not been resolved. See Editor's Note, Gray v. Cincinnati S. Ry., 11 F. 683, 687-88 (C.C.S.D. Ohio 1882) (holding that blacks may be given segregated accommodations in railroad cars, but may not be excluded altogether); see also Smoot v. Kentucky C. Ry., 13 F. 337, 344 (C.C.D. Ky. 1882) (declaring the Act unconstitutional without reaching the issue of separate but equal accommodations); Cully v. Baltimore \& O.R.R. Co., 6 F. Cas. 946, 948 (D. Md. 1876) (No. 3466) (same); Charge to Grand Jury-Civil Rights Act, 30 F. Cas. 1005, 1006 (C.C.W.D. Tex. 1875) (No. 18,260) (same). For a contemporary discussion of the statute's constitutionality, correctly predicting the Supreme Court's decision, see Cocke, Constitutionality of the Civil Rights Law, I S.L. REv. (new series) 193, 197-200 (1875). Several other cases are discussed in Franklin, The Enforcement of the Civil Rights Act of 1875, 6 PROLOGUE 225 (1974), and in Riegel, supra note 1, at 20-37.

127. Green v. City of Bridgeton, 10 F. Cas. 1090, 1093 (S.D. Ga. 1879) (No. 5754).

128. In 1873, however, the Supreme Court expressly rejected a proposed "separate but equal" construction of a different federal statute. In 1863, Congress passed an act permitting a railroad that operated in Virginia to extend its routes into Washington, D.C. The federal charter required that "no person shall be excluded from the cars on account of color." Railroad Co. v. Brown, 84 U.S. 445,452 (1873). The railroad tried to comply with the charter by using separate, identical cars for whites and blacks and switching the racial designation of the cars for each return trip. When a black woman attempted to board the white car she was put out "with force, and . . some insult." Id. at 488. She sued under the federal charter, and won fifteen hundred dollars; the Supreme Court affirmed. Id. at 449,453 . The "on account of color" language in the charter, however, was stronger than that in the Civil Rights Act. 
Brown v. Board of Education, ${ }^{129}$ and there is little left to add. ${ }^{130}$ It is worthwhile, however, to look at a "separate but equal" case that came to the United States Supreme Court in 1890, six years before Plessy v. Ferguson was decided. In 1888 the state of Mississippi passed a statute identical to the Louisiana statute uplield in Plessy. ${ }^{131}$ The Mississippi law required that railroads carrying passengers within the state provide "equal, but separate, accommodations for the white and colored races." 132 The Louisville, New Orleans and Texas Railway Company violated the statute and appealed its conviction to the Supreme Court. ${ }^{133}$ The lawyer who argued the railroad's claim that the statute was unconstitutional was Wiley Pope Harris, former United States Congressman, a leader of the Mississippi bar, and a prominent constitutional lawyer. However, in 1890 it did not occur to Harris to argue that the separatebut-equal statute violated the equal protection clause. Never once in his brief did he even suggest that racial separation aboard railroad cars raised any fourteenth amendment issues. Instead lie argued only that the

129. 347 U.S. 483 (1954).

130. See, e.g., R. Berger, Government By Judiciary: THe Transformation of the FOURTEENTH AMENDMENT 99-133 (1977) (arguing that the fourteenth amendment was not originally intended to prohibit segregation and that the Brown decision therefore revised the meaning of the amendment); B. REAMS \& P. WILSON, SEgREGATION AND THE FourTEENTH AMENDMENT IN THE STATEs (1975) (demonstrating that the southern states almost simultaneously ratified the fourteenth amendment and enacted segregation statutes, even though at the time they were controlled by Republican legislatures); Bickel, The Original Understanding and the Segregation Decision, 69 HARV. L. REv. 1, 40-56 (1955) (analysis of framers' intent in enactment of the fourteenth amendment); Kelly, The Fourteenth Amendment Reconsidered, 54 MicH. L. REv. 1049, 1086 (1956) (same). In the reargument of Brown, the respondent showed that, when the fourteenth amendment was ratified, 24 of the 37 states in the Union maintained statutory school segregation. Ten of the remaining 13 had no statutes at all. See Brief for the State of Kansas on Reargument at 34, 91-92, Brown v. Board of Education, 347 U.S. 483 (1954).

For interesting perspectives on the effort to determine the original understanding of the framers of the fourteenth amendment, see J. ELY, DEMOCRACY AND D1STRUST 1-41 (1980) (calling for a broad interpretation of the fourteenth amendment); C. MILLER, THE SUPREME COURT AND THE USES OF HisTORY 100-18 (1969) (same).

131. The Louisiana statute at issue in Plessy v. Ferguson provided:

That all railway companies carrying passengers in their coaches in this State, shall provide equal but separate accommodations for the white, and colored races, by providing two or more passenger coaches for each passenger train, or by dividing the passenger coaches by a partition so as to secure separate accommodations: provided that this section shall not be construed to apply to street railroads.

Act of July 10, 1890, No. 111, $§ 1,1890$ La. Acts 152, 153 (emphasis in the original). The Mississippi statute at issue in Louisville, N.O. \& T. Ry. v. Mississippi, 133 U.S. 587 (1890), provided:

That all railroads carrying passengers in this State (other than street railroads) shall provide equal but separate accommodations for the white and colored races, by providing two or more passenger cars for each passenger train, or by dividing the passenger cars by a partition so as to seeure separate accommodations.

Act of Mar. 2, 1888, ch. 27, $\$ 1,1888$ Miss. Laws 48, 48.

132. Act of Mar. 2, 1888, ch. 27, $\S 1,1888$ Miss. Laws 48, 48.

133. Louisville, N.O. \& T. Ry. v. Mississippi, 133 U.S. 587, 588 (1890). 
Mississippi law was an unconstitutional state regulation of interstate coninierce. ${ }^{134}$ When Justice Brewer wrote his opinion upholding the statute he also did not mention the fourteenth amendment. He merely observed that the statute had been construed by Mississippi's own courts to apply only to passengers whose entire journey was within the state. As a result, there was no impermissible interference with interstate travel. ${ }^{135}$

Justice Harlan was the only dissenter. He believed that the nation's railway system was such an imtrinsic part of interstate commerce that even an intrastate segregation rule was an impermissible burden on interstate transportation. ${ }^{136}$ However, Harlan's dissent would have been the perfect opportunity to raise some objections to the statute under the fourteenth aniendment. Six years later Harlan used the new amendment as the basis for a passionate dissent in an identical case: Plessy v. Ferguson. ${ }^{137}$ But in the Mississippi case he limited his analysis to the commerce clause. ${ }^{138}$

In 1890 it siniply had not occurred to either Harlan or Wiley Pope Harris that the equal protection clause had been meant to prohibit stateenforced separate but equal accommodations. When the argument was raised in Plessy it was an innovation-suggested by the railroad in a contrived case as a last resort to strike down a statute that was making it very expensive to run a railroad. ${ }^{139}$ The evidence thus indicates that the idea that separate but equal accommodations violated the equal protection clause was not judicially considered until sometime between 1890

134. Id. at 591.

135. Id. at 591-92; see also C. BARNES, supra note 1, at 7-8 (summarizing subsequent history of interstate/intrastate distinction in race discrimination cases involving transportation).

136. Louisville, N.O. \& T. Ry. v. Mississippi, 133 U.S. 587, 594 (1890) (Harlan, J., dissenting).

137. 163 U.S. 537, 555-64 (1896) (Harlan, J., dissenting).

138. Louisville, N.O. \& T. Ry. v. Mississippi, 133 U.S. 587, 592-95 (1890) (Harlan, J., dissenting). Professor Schmidt looks at the same evidence and attacks the Supreme Court's use of "conclusory verbalisms" in the Mississippi case, but he never deals with the failure of both Harris, the chief litigant, and Justice Harlan to raise the argument that the segregation statute violated the equal protection clause. See A. BICKEL \& B. SCHMIDT, supra note 1, at 751. If the argument was even considered plausible in 1890, one would expect these individuals to have raised it. In the case of Harlan (but not of Harris) one possible explanation is that, because the equal protection issue was never argued before the Court, Harlan felt constrained by the prevailing canons of judicial restraint not to raise a constitutional issue that had not been presented below.

139. See R. KLUGer, supra note 1, at 73 (suggesting that Plessy was collusively brought). Whether Plessy was collusive or not, the railroads had a strong interest in overturning such statutes. The defendant in Louisville, N.O. \& T. Ry. v. Mississippi argued that the statute would "greatly hinder, delay, and obstruct the defendant in making its interstate connections with other carriers of passengers." Brief of the State of Mississippi at 4, Louisville, N.O. \& T. Ry. v. Mississippi, 133 U.S. 587 (1890); see also C. BARNES, supra note 1, at 12 (indicating that transit lines objected to the expense of supplying extra cars for blacks, but backed down in the face of white pressure for segregation). 
and 1896 - more than a generation after the fourteenth amendment was ratified.

Neither the fourteenth amendment nor the 1875 Civil Rights Act was designed to force the racial integration of public facilities in any part of the country. The Radical Republicans did not impose integration on the occupied South. Most of them did not have integration in mind when the Civil Rights Acts were passed, and the judiciary did not read a social integration requirement into either the Civil War amendments or the statutes passed under them.

Courts of the period distinguished between political and social equality when they discussed the status of the freedman. According to the Supreme Court in Plessy, the fourteenth amendment protected blacks politically but not socially. ${ }^{140}$ That distinction was not new; Judge Robert Dick recognized it in 1875 , when he instructed a grand jury that the Civil Rights Act was not intended "to confer any rights or privileges of social equality among men," but only legal or political equality. ${ }^{141}$ In fact, the distinction between political and social equality was much older than the Civil War. ${ }^{142}$

Liberalism in politics, and environmentalism in the social sciences, have given twentieth century Americans an extraordinarily broad view of the meaning of "equality." The "All Men Are Created Equal" clause of the Declaration of Independence has come to mean "All men are created equal in every respect." Simce the 1940's few people have believed that some races are inferior in intellect, moral sensitivity, or adaptibility to modern society. Cultural relativism has taught us that races of people are not inferior or superior. They are merely different. To be sure, certain problems have given cultural relativists some difficulty. The notion that all races have equal intelligence has probably been the hardest to

140. Plessy, 163 U.S. at 551-52.

141. Charge to Grand Jury-The Civil Rights Act, 30 F. Cas. 999, 1000 (C.C.W.D.N.C. 1875) (No. 18,258$)$.

142. Richard Kluger was horrified to find the distinction between social and political equality elaborated upon in Plessy: "It would be onerous work to find a more unsupported or unsupportable sentence in the annals of American jurisprudence. The universally acknowledged, exhaustively documented intention of the framers of the Fourteenth Amendment had been to remove degradation of the Negro from the realm of legitimate legislative ends." R. KLUGER, supra note 1, at 74. This is a simple case of reading history backwards: the framers of the fourteenth amendment must have had Brown v. Board of Education in mind when they drafted the equal protection clause. In fact, however, the framers of the fourteenth amendment were creatures of the nineteenth century who necessarily shared its scientific racial views. Kluger's "unsupported" distinction between social and political equality has been in existence since at least the days of Thomas Jefferson. See infra notes 145-48 and accompanying text; see also A. BICKEL \& B. SCHMIDT, supra note 1, at 753. One recent study suggests that discussion of racial integration was virtually nonexistent in the fourteenth amendment ratification process. See generally J. JAMES, THE RATIFICATION OF THE FOURTEENTH AMENDMENT (1984). 
defend, for there are too many tests in which one race performs consistently better than others. But even here cultural relativism seems to justify equality. Intelligence, after all, must be measured instrumentally. Useful intelligence is the ability of an organism to solve the problems that its environment presents. Each culture is adapted to its own environment, and each must have its own standards for intelligence. We perpetuate racist stereotypes when we give one culture an intelligence test designed for the members of a different culture; they invariably perform poorly, and we then have "proof" that blacks or Indians or members of some other racial minority are inferior to the Caucasians who have been supplying the tests all along. ${ }^{143}$

Before the age of cultural relativism, however, equality was not so big a word. ${ }^{144}$ The notions of equality that inspired democracy in the French and American Enlightenment were radical to be sure-but not nearly as radical as liberal historians have made them out to be. Thomas Jefferson was unquestionably sincere when he wrote that all men are created equal-but he also sincerely believed that blacks had inherently inferior intelligence and animalistic sexual appetites, and that they occupied a link in the Great Chain of Being somewhere above the orangutan but substantially below the Caucasian. ${ }^{145}$

To Jefferson only one thing made the black man equal to the white. The African, in common with mankind but unlike the animals, had been divinely blessed with the "moral sense." 146 The black man possesses "in-" tegrity . . . [,] benevolence, gratitude and unshaken fidelity" just as any white man does. ${ }^{147}$ The moral sense is the preeminent human endowment, beside which all other human characteristics are merely incidental. One person may be more intelligent than another, and another may be stronger. But all of them, if they are human, possess the fundamental

143. See S. GouLD, supra note 24 , at $238-96$ (discussing the historical problem of reification in intelligence testing); R. LEWONTIN, S. ROSE, \& L. KAMIN, NoT IN OUR GENES: BIoLOGY, IDEOLOGY, AND HUMAN NATURE 83-129 (1984) (discussing the problem of reification in intelligence testing and the use of intelligence testing to support biological determinism).

144. For interesting perspectives on the meaning of equality in American constitutional history, see Handlin, The Quest for Equality, 1979 WASH. U.L.Q. 35 (discussing the changing nature of the concept of equality since the time of the Declaration of Independence); J. POLE, THE PURSUIT OF EQUALITY IN AMERICAN HisTORY (1978) (discussing the historical sources and character of the discrepancy between the public commitment to equality and the public concern with translating that commitment into policy).

145. See generally D. Boorstin, The Lost World of Thomas JefFerson 34-40 (Beacon Press ed. 1960) (discussing the Jeffersonian belief that every kind of natural object was a link in an unbroken chain of being stretching from the mineral up to man); A. LoveJoY, THE GREAT CHAIN OF BEING (1936) (discussing the history and development of the concept of the chain of beings).

146. See G. Wills, Inventing America: JefFerson's Declaration of INDEPENDENCE 218-28 (1978).

147. Id. at 224 (quoting T. JefFerson, Notes ON THE State of Virginia 142-43 (1972)). 
virtues that give people awareness of their existence as social beings. They live in society by reflection, while the animals live merely by instinct. This idea of equality was not predicated on similar intelligence or common cultural perceptions. It was built on the simple uniqueness of man as a moral creature. ${ }^{148}$

Jefferson's idea of equality would make it easy for Judge Dick, and later for Justice Brown in Plessy, to distinguish between political equality and social equality. To have political equality was to have the same basic human rights against the state that the white person has-the right to own property, to vote, to plead in court, and to share equally in the costs and benefits of government. As a participating member of society, every person deserved these things, heredity and intelligence notwithstanding. Social equahty, on the other hand, implied something radically different. Social equahty was equality measured not against the state, but against other individuals. The black person who wanted to vote was imposing on the state, but the black person who wanted to ride in an integrated railroad car or attend an integrated college was imposing his presence on the individuals who composed the majority - and they did not want him there. The freedman could assert his social rights only at the obvious expense of the rights of someone else. "Every man has a natural and inherent right of selecting his own associates," Judge Dick wrote in 1875 , "and this natural right cannot be properly regulated by legislative action, but must always be under the control of individual taste and inclination." 149 The fourteenth amendment, of course, imposed an obligation only on the states, not on private individuals. It had been designed to guarantee political equality, not to enforce social equality. ${ }^{150}$

The fourteenth amendment concept of state action, which facilitated the Supreme Court's declaration that the 1875 Civil Rights Act was un-

148. The great antinomy in Jefferson's thought was that he simultaneously believed that all people were "created equal," but that blacks were inferior in mental capacity. See G. WiLLS, supra note 146, at 218-28 (analyzing the conflict in Jefferson's thought). Jefferson's attitudes toward blacks and slavery are discussed in W. COOPER, LIBERTY AND SLAVERY: SOUTHERN POLITICS To 1860, at 36 (1983) (Jefferson opposed slavery but supported segregation of the races); J. MILLER, THE WOLF BY THE EARS: ThOMAS JefFerson AND SLAVERY (1977) (detailed analysis of Jefferson's attitudes towards blacks and slavery). The best essay discussing how liberals such as Jefferson could simultaneously assert broad ideals of equality and also maintain the inferiority of American blacks is $\mathbf{E}$. Morgan, american Slavery, American Freedom: The Ordeal of Colonial Virginia 4 6, 375-76 (1975).

149. Charge to Grand Jury-The Civil Rights Act, 30 F. Cas. 999, 1000 (C.C.W.D.N.C. 1875) (No. 18,258).

150. Even the most radical Republicans distinguished between political and social equality, both before and after the Civil War. They wanted blacks to have the former, but denied that blacks should have the latter. See H. BELZ, A NEW BIRTH OF FreEdom: the REPUBLICAN PARTY AND FREEDMEN'S RIGHTS, 1861 To 1866, at 138-56 (1976) (discussing the concept of equality before the law as meaning political, not social, equality). 
constitutional, ${ }^{151}$ rather effectively drew the line between the kind of race discrimination that was appropriate in the 1880's and the kind that was not. Americans valued greatly the idea that they lived in the most democratic and egalitarian of nations; at a relatively low cost they could now deliver to the newly freed American black a measure of participation in the political process and a certain amount of access to the public facilities from which he traditionally had been excluded. They could justify permitting the black to be a part of American society-indeed, they had a strong economic interest in preventing him from being a burden. On the other hand, the science of the day indicated that close racial mixing would impose costs far greater than the benefits to be derived therefrom. Although that science had relatively little to say about political equality, it had a great deal to say about social equality.

\section{Social Science and Social Planning in a Racist Society}

A great deal of nineteenth-century science was implicit in Judge Dick's distinction between political and social equality. If politics had shown that the American state was flexible enough to accommodate a diverse citizenry, anthropology and sociology were beginning to show that human beings were extraordinarily inflexible in the matter of racial amalgamation. It was easy for the state to give the Afro-American the vote, but it was terribly difficult for the white person to share his seat with an African.

\section{A. The Social Science of the Gilded Age.}

Anthropology became a science at a time when the sciences were obsessed with new developments in biology. As a result the new science was dominated for almost a century by biological analogies. ${ }^{152}$ To explain man's physical structure was to explain mankind. America's first great contributor to the newborn science was Samuel George Morton, the Philadelphia physician with the white mustard seeds. ${ }^{153}$ Morton developed quite a following of scientists who believed that there were broad

151. The Civil Rights Cases, 109 U.S. 3, 10-19 (1883).

152. See M. HARRis, The Rise of ANTHRopological Theory 80-179 (1968) (discussing the effect of anthropology on the theories of racial determinism, Spencerism, and Darwinism). The biological analogies also spilled into jurisprudence. See, e.g., Elliott, Holmes and Evolution: Legal Process as Artificial Intelligence, 13 J. LEGAL STUD. 113 (1984) (discussing Holmes's theories on the evolution of law); Holmes, Law in Science and Science in Law, 12 HARV. L. REV. 443 (1899) (same); Hovenkamp, Evolutionary Models in Jurisprudence, 64 TEx. L. REV. — (forthcoming, 1985) (discussing evolutionary theories in jurisprudence).

153. See supra notes 50-51 and accompanying text. 
and permanent differences among racial types. ${ }^{154}$ Sanford Hunt, upon whom Kentucky's Attorney General Breathitt had relied in Berea College, ${ }^{155}$ was fascinated by Morton's findings. When Hunt was working for the United States Sanitary Commission during the Civil War he prepared a report on the physical, emotional, and mental characteristics of the black soldier. The first part of Hunt's report was behavioral. $\mathrm{He}$ concluded that blacks were imitative, cheerful, rhythmical (they marched well at night), and not very intelligent. These characteristics made the Afro-American a good foot soldier but a bad officer. ${ }^{156}$

The problem of black intelligence bothered Hunt. He wanted to be fair, and he wanted his conclusions to be as universal as possible. Hunt concluded that artificial intelligence testing was unsatisfactory because the tests measured too many environmental influences, and most blacks were illiterate. ${ }^{157}$ The typical black soldier was a former slave. All his life he had been forced into the kind of existence that would naturally tend to dull one's wits. Hunt decided that cranial capacity and brain weight would be much more accurate indicators of innate racial intelligence than any skills testing of living subjects. He studied the results of 405 autopsies of white and black soldiers and came to the conclusions that Attorney General Breathitt cited in his brief. ${ }^{158}$ Much of the physical anthropology of the second half of the century was derived from these data collected by Hunt and others during the Civil War. ${ }^{159}$

The ease with which Hunt was able to separate genetic and environmental determinants of intelligence reveals a naiveté about human development that dommated social science until the twentieth century. By 1908, when Attorney General Breathitt used Hunt's anthropological data before the Supreme Court, the idea that one could measure intelli-

154. S. Gould, supra note 24, at 30-112; see W. STANTON, supra note 50, at 24-190 (discussing Morton's work and the scientific community's reaction to it).

155. See supra notes $43-47$ and accompanying text.

156. Hunt, The Negro as a Soldier, 11 ANTHROPOLOGiCAl REv. 40, 42-43, 48-54 (1869).

157. Id. at 49.

158. See supra notes $43-47$ and accompanying text.

159. See Hunt, supra note 156, at 48-54; see also supra notes 35-54 and accompanying text. Other studies were conducted by anthropologist J. Bernard Davis. Davis was more theoretical than Hunt, and was particularly interested in using data concerning brain size to explain the evolutionary development of the human race. His conclusions generally supported Hunt's. See Davis, On the Weight of the Brain of the Negro, 7 ANTHRopological REV. 190, 190-92 (1869) (refining the data collected by Hunt and concluding that brain weight is a racial characteristic, but noting that there is sometimes a negative correlation between brain weight and level of civilization); Davis, Contributions Toward Determining the Weight of the Brain in the Different Races of Man, 16 Proc. RoYAL. Soc'Y LONDON 236, 239-40 (1868) (survey of average brain weights of various races, concluding that the average brain weight of the African races was lower than that of the European races). These same data were used in late nineteenth-century America to support a genetic theory of criminal behavior. See Hovenkamp, supra note 47, at 560-63 (1981). 
gence simply by weighing brains was in general disrepute. ${ }^{160}$ However, psychologists were only beginning to realize that the separation of genetic and environmental factors in race development could be an extremely complex task. ${ }^{161}$ Even if Breathitt had used the most up-to-date scientific data available he could still easily have been led to the same conclusion - that blacks were inherently, permanently inferior to whites in intelligence, and that amalgamation of the two races could seriously threaten the integrity of the white race. ${ }^{162}$

Most of the physical anthropologists of the Gilded Age were probably evolutionists. The immediate effect of Darwin's work was, however, to confirm and strengthen long-established ideas about black inferiority. The theory of evolution gave direction and motion to what in Jefferson's time had been a rather static concept. For Jefferson the African occupied a fixed position somewhere below the white man. For Gilded Age American anthropologist Lewis Henry Morgan, however, the black man was inferior to the white and was falling further behind every year. ${ }^{163}$

Morgan, a New York lawyer who turned to ethnology, was America's most famous Gilded Age anthropologist. He adapted Darwinian natural selection to a Spencerian notion of absolute cultural progress. He concluded that the different human races were in different stages of physical and cultural evolution. Morgan names the three general stages of human cultural achievement: savagery, barbarism, and civilization. ${ }^{164}$ In Morgan's view, "[t]he Aryan family represents the central stream of human progress, because it produced the highest type of mankind, and because it has proved its intrinsic superiority by gradually assuming the control of the earth."165 The African race, on the other hand, was still in the middle stage of barbarism.

Like Darwin, Morgan believed that species or varieties of any organisms in close physical proximity compete with each other. ${ }^{166}$ Morgan applied this principle to cultural as well as to physical development. $\mathrm{He}$ believed that the human races differed from the lower animals in that they no longer relied on brute strength but on intelligence and inventiveness to survive. The more advanced the culture, the more mental powers

160. See S. GouLD, supra note 24 , at $108-12$ (discussing the fallacies in craniometric research and theories).

161. See generally H. CRAVENS, supra note 24 (history of the controversy over the impact of genetic versus environmental factors on cultural development).

162. See supra notes $25-63$ and accompanying text.

163. See generally L. MORGaN, ANCIENT SOCIETY (1877).

164. Id. at 3-18.

165. Id. at 553.

166. See id. at $29-45,550-54$. 
had replaced physical strength as the basic survival weapon. ${ }^{167}$ In this respect the Afro-American was hopelessly outclassed. If the African had been left in isolation in his homeland, reasoned Morgan, his culture might have developed to a civilized maturity. However, when an inferior culture confronts a superior one the former must give way. Blacks sharing the same environment with whites were unable to compete; black culture and eventually the black race itself would disappear. ${ }^{168}$

The idea that the black race was so inferior that it would eventually become extinct was popular at the end of the nineteenth century. Anthropologist Frederick L. Hoffman believed that emancipation had been the worst thing that ever happened to the Afro-American. The enslaved African had always been cared for. He had performed hard but simple labor, and in exchange he had been relieved from making all the decisions that freedoin in a complex society entails. As freedmen, the Africans were not equipped to deal with the complexities of their new culture. Hoffman found evidence that after the Civil War the black mortality rate had increased, blacks had developed a much higher incidence of several diseases, and their general standard of living had declined. Turned loose in a civilized society, the African was doomed. ${ }^{169}$

Many American Anglo-Saxons could have lived with that conclusion. To them, a nation without blacks was thinkable, if not appealing. But interracial inarriage destroyed the simplicity of the evolutionary idea. Although social scientists generally agreed about the characteristics of the "pure" African, the hybrid was a mystery, even in the late nineteenth century, and there was not much uniformity of scientific opinion about him. Sanford Hunt believed that the mental capacity of the mulatto varied with the amount of white blood that flowed in his veins. ${ }^{170}$ Frederick Hoffman thought all mulattoes were inferior to members of either race. ${ }^{171}$ Nathaniel Southgate Shaler, a prominent Harvard professor, believed that the mulatto was less healthy, shorter-lived, and less fertile than members of either the black or the white race. Shaler's research supported the popular idea that most mulattoes grow up with "disharmomic" features-large frames combined with small heart and kidneys, for example, or large teeth tightly crowded into an undersized mouth. ${ }^{172}$

167. Id.

168. Id.

169. Hoffman, Race Traits and Tendencies of the American Negro, 11 Punlications AM. ECON. A. 1, 310-29 (1896).

170. See Hunt, supra note 156, at 52 .

171. See Hoffman, supra note 169.

172. Shaler, Our Negro Types, 29 CuRRENT LiT. 45, 46 (1900) (mulattoes are "general[ly] of feeble vitality, rarely surviving beyond middle age"). 
But worse yet were the mulatto's insoluble moral and psychological problems. "From the white he inherits a refinement unfitting him for all work which has not a certain delicacy about it," concluded Shaler; however, from his black parent the mulatto acquires "a laxity of morals which, whether it be the result of innate incapacity for certain forms of moral culture or the result of an utter want of training in this direction, is still unquestionably a negro characteristic." 173 In short, the mulatto was an outcast in both worlds-too civilized to be comfortable with the black, but too primitive to live with the white without giving offense.

Although many of the racists who opposed interracial sexual relations were evolutionists, they cast the problem in a scientific paradigm that was more Lamarckian than Darwinian. Jean Baptiste Lamarck was a pre-Darwimian evolutionist who did most of his writing at the beginning of the nineteenth century. ${ }^{174}$ Lamarck never hit upon the theory of natural selection. Rather, he explained evolutionary progress as the instinctive "unconscious striving" of each member of a species to better itself and its progeny. To this theory Lamarck coupled the notion of the inheritance of acquired characteristics-for example, a cougar that develops strong legs from hard running could pass its superior muscles on to its offspring. ${ }^{175}$

During the late nineteenth century many biologists explained evolution in a nodified Lamarckian paradigm. This neo-Lamarckianism dominated popular theories about race throughout the Progressive Era. According to the neo-Lamarckian evolutionary theory, any organism's "unconscious striving" naturally attracts it to the most superior mate. The male's instinct to better the position of its species demands that it find the best possible female. Thus in many species the males fight among eacli other, and the winner gets first choice of the females. In this

173. Id. at 47; see N. Shaler, The Neighbor: The Natural History of Human ConTACTS 59-64 (1904) (arguing that miscegenation is undesirable); Shaler, Scicnce and the African Problem, 66 ATL. MONTHL y 36, 37 (1890) (same). For further discussion of the Gilded Age perception of mulattoes, see generally J. MenCKe, Mulattoes and Race Mixture: American AtTItudes AND IMAGes, $1865-1918$ (1979); I. Newby, JiM Crow's Defense: ANTI-Negro Thought in America, 1900-1930, at 132-35 (1965); J. Williamson, New People: MiscegenaTION AND MULATTOES IN THE UNITED STATES (1980).

174. See L. Eiseley, Darwin's Century 46-52 (1958); see generally J. LAMARCK, ZoologiCAL Philosophy (London 1809).

175. See L. EiSELEY, supra note 174, at 119-25 (discussing the work of William Wells, an early evolutionist who expounded on Lamarckian theories and whose work was later recognized by Darwin); H. HovenKAMP, supra note 58, at 189-210 (1978) (discussing Lamarckianism and early American science). 
way the best characteristics of the best pair are united, thus improving the species. ${ }^{176}$

Progressive Era racial theorists used the neo-Lamarckian paradigm to explain what to them seemed to be a universal phenomenon: the intense sexual attraction that blacks had for whites-particularly black males for white females. The whites, after all, were the superior strain. Any white person seeking out a mate would be naturally repelled by the thought of marriage to an inferior individual. The black, on the other hand, occupied a lower rung on the evolutionary ladder. He was instinctively striving to better his race and was naturally attracted to more superior types. For the black, interracial mating meant evolutionary progress; for the white, it meant regression. To many racists this meant that the white race had a natural tendency to preserve its racial purity. The natural tendency of the black race, however, was to blend with the whites until the racial identity of the blacks entirely disappeared. ${ }^{177}$

How to combat the black male's urge for the white female was a question of social control. Self-help, to be sure, was one method-and lynchings of black males accused of sexual misconduct were relatively common in the New South. ${ }^{178}$ In addition, statutory prohibitions of interracial marriage were universal in the South and relatively common in the North and the West. ${ }^{179}$ Louisiana prohibited them as early as 1810 , North Carolina in 1830, and Arkansas in 1838. ${ }^{180}$ During the Progressive Era many states in both the North and the South tried to make miscegenation statutes more effective by providing for the punishment of any clergyman or public official who performed an illegal marriage. The presumption was that the official would know the law even if the illiterate bride and groom did not. ${ }^{181}$

Statutory controls on interracial marriage and sexual relations were such an intrinsic part of the American value system during the Gilded Age that few people bothered to challenge their constitutionality. No

176. See H. Cravens, supra note 24 , at 35 (discussing the neo-Lamarckian view of heredity and evolution).

177. See, e.g., E. Talbot, Degenneracy: Its Causes, SignS and Results 99-103 (1904) (discussing negative effects of racial mixing); Dixon, The Morbid Proclivities and Retrogressive Tendencies in the Offspring of Mulattoes, 20 J. A.M.A. 1, 1-2 (1893) (same); see generally J. HALLER, OUTCASTS FROM EVOLUTION: SCIENTIFIC ATTITUDES OF RACIAL INFERIORITY 1859-1900, at 5160 (1971) (discussing studies that analyzed the sexual habits of blacks).

178. However, the common perception that nearly all blacks who were lynched had been accused of sex crimes is probably wrong. In 1901 this was true of only one lynching in five. See H. Knuth, The Climax of American Anglo-Saxonism, 1890-1905, at 199 (1958) (unpublished Ph.D. dissertation, Northwestern Univ.). Historically, the vast majority of interracial sexual contacts involved white men and black women. See Williamson, supra note 173, at 5-60, 88-94 (surveying the history of interracial relationships).

179. C. Mangum, The Legal Status of the Negro 236-73 (1940).

180. Id. at $241-42$.

181. See id. at $242-43$. 
miscegenation case reached the Supreme Court. ${ }^{182}$ However, in 1882 the Supreme Court dismissed a fourteenth amendment challenge to an Alabama law that made interracial adultery a much more serious offense than adultery of the ordinary variety. Justice Field wrote a two-page opinion that never cited a case. He noted only that the statute was nondiscriminatory because it applied equally to whites and blacks. ${ }^{183}$

The social costs of racial mixing and miscegenation were perceived as so high that few seriously considered permitting the practices. In the scientific view of the day a racially mixed couple-no matter how happy they might be-were likely to produce inferior offspring that would be a lifetime burden on society and were guaranteed to weaken and contaminate both the white and the black races. In such a paradigm the costs of social integration far exceeded any benefits.

\section{B. Social Planning: Responding to Social Science Data.}

In the first two decades of the twentieth century the popular horror of racial amalgamation reached its apogee. Progressive Era politicians supported a wider role for government in social planning than did their Gilded Age predecessors, and they looked for broader methods of social control than mere antimiscegenation statutes. The most obvious way to ensure separation was to force blacks and whites to live in different places. In 1910 Baltimore passed the ultimate antiamalgamation statute-an ordinance that zoned separate residential districts for blacks and whites. Within six years more than a dozen southern cities had followed suit. 184

The ordinance passed by the city of Louisville, Kentucky, was typical. ${ }^{185}$ It prevented any black person from moving into "any house upon any block upon which a greater number of houses are occupied . . . by

182. Some miscegenation statutes were challenged in the lower federal courts. In Ex Parte Kinney, 14 F. Cas. 602 (C.C.E.D. Va. 1879) (No. 7825), Judge Hughes rejected a challenge brought under the fourteenth amendment's privileges and immunities clause. That clause, the court concluded, protected only rights of national citizenship, and marriage was clearly a right of state citizenship. Id. at 604-05. That analysis was undoubtedly correct in light of the Supreme Court's interpretation of the privileges and immunities clause in The Slaughter-House Cases, 83 U.S. (16 Wall.) 36, 73-75 (1873) (privileges and immunities clause protects only rights of national citizenship). Judge Hughes also concluded that the Virginia miscegenation statute was nondiscriminatory because it applied equally to blacks and whites. Ex Parte Kinney, 14 F. Cas. at 605 . The United States Supreme Court overturned a miscegenation statute when it addressed the issue for the first time in 1967. Loving v. Virginia, 388 U.S. 1, 2 (1967).

183. Pace v. Alabama, 106 U.S. 583, 585 (1882).

184. See A. B1CKEL \& B. SCHM1DT, supra note 1 , at 791 .

185. For a description of the text of the statute, see Buchanan v. Warley, 245 U.S. 60, 70-72 (1917). Other cases, as well as a discussion of a draft of Holmes dissent that was never used, appear in A. BICKEl \& B. SCHMIDT, supra note 1, at 790-817. 
white people than are occupied . . . by colored people."186 The second section of the law likewise made it illegal for a white person to move onto a predominantly black block. ${ }^{187}$ With the statute in effect, Louisville would eventually have had no racially mixed residential blocks.

Shortly after the Louisville ordinance was passed, Robert Buchanan, a white man, contracted to sell his home to a black man named William Warley. At the time there were ten houses on Buchanan's block, and eight of them were occupied by whites. Under the new ordinance Warley could not occupy the house he had agreed to purchase. Warley refused to pay the price and Buchanan sued him. As a result the case came into the Kentucky court system in a peculiar posture. Warley the black man argued that the racial zoning statute was constitutional and that because of it he should be excused from performing his contract. Buchanan the white man, on the other hand, argued that the statute was unconstitutional and could not provide Warley with a defense. ${ }^{188}$

Judging from the speed with which the newly formed National Association for the Advancement of Colored People (NAACP) moved in and agreed to represent Anglo-Saxon Buchanan against African Warley, ${ }^{189}$ it is likely that the case had been "tailored" a bit in order to present it to the Supreme Court in the most attractive way. The posture of the case made it obvious that racially exclusive zoning could do as much damage to the property rights of white persons as to the rights of

186. Buchanan v. Warley, 245 U.S. 60, 70-71 (1917). The Baltimore and Atlanta statutes were slightly different from the Louisville ordinance. They made it illegal for any white person to move onto a block occupied exclusively by blacks, or for any black to move into a block occupied exclusively by whites; mixed blocks could remain mixed. State courts generally held the ordinances unconstitutional, or void for other reasons. See Carey v. City of Atlanta, 143 Ga. 192, 202, 84 S.E. 456, 460 (1915) (Atlanta ordinance constituted taking of property without due process of law); State v. Darnell, 166 N.C. $300,305,81$ S.E. 338, 340 (1914) (ordinance exceeded powers of state because it restricted the transferability of property); State v. Gurry, $121 \mathrm{Md}$. 534, 548-51, 88 A. 546, 552-53 (1913) (Baltimore ordinance was void because it affected vested property rights). However, the Virginia Supreme Court found Richmond's ordinancc valid as long as it was applied to persons whose rights, either as owners or as tenants, in the particular piece of property affected by the statute had accrued after the statute was passed. Hopkins v. Richmond, $117 \mathrm{Va} .692,697-98,86$ S.E. 139, 141 (1915), overruled in Irvine v. Clifton Forge, 124 Va. 781, 97 S.E. 310 (1918); see also Harden v. City of Atlanta, $147 \mathrm{Ga} .248,250-53,93$ S.E. 401, $402-03$ (1917) (upholding Atlanta statute that did not affect vested property rights), overruled in Glover v. City of Atlanta, 148 Ga. 286, 96 S.E. 562 (1918) (per curiam). The earliest residential exclusion statutes came from California and were directed against the Chinese, not against blacks. These earlier statutes did not apply equally to all personsthey simply excluded the Chinese from certain parts of town. They were invalidated under the equal protection clause. In re Lee Sing, 43 F. 359, 360-62 (C.C.N.D. Cal. 1890).

187. Buchanan v. Warley, 245 U.S. 60, 70-71 (1917).

188. For more on the factual background of the case, see Rice, Residential Segregation by Law, 1910-1917, in 34 J. S. HIST. 179, 182-89 (1968); see also G. FrEDRICKSON, WhITE SUPREMACY 25354 (1981) (discussing history and development of residential segregation).

189. It was particularly ironic in light of the fact that Warley was prominent in the Louisville NAACP. See A. BICKEL \& B. SCHMIDT, supra note 1, at 805. 
blacks. ${ }^{190}$

Kentucky's highest court upheld the statute as a rational exercise of the state's police power, citing Berea College. ${ }^{191}$ By the time the United States Supreme Court agreed to hear the case it had generated a great deal of publicity. Racial zoning ordmances were becoming very popular, and eventually most of the South and parts of the North would have passed them.

Moorfield Storey, a prominent Boston attorney and the national president of the NAACP, argued the plaintiff's case on two days in April of 1916. Two attorneys working for the City of Louisville argued for the constitutionality of the statute. In his oral argument Storey made an argument that was not presented in his brief: that racial mixing was essential to America's cultural vitality, and any state policy of segregation was unreasonable. Consistent with this position, he was forced to acknowledge that he believed statutes forbidding interracial marriage and integrated schools were also unreasonable and unconstitutional uses of state police power. ${ }^{192}$

This argument for the wisdom of racial amalgamation intrigued the Court, and it held the case over for reargument. ${ }^{193}$ Stuart Chevalier and Pendleton Beckley, the attorneys representing the City of Louisville, prepared a long reply brief for the April 1917 reargument. They told the Court that they had been astounded when Moorfield Storey tried to make the case turn on the reasonableness of racial amalgamation. ${ }^{194}$ To bolster his argument, Storey had "cited various scientific authorities" in

190. The collusiveness of the case is further borne out by the language of the written offer that Warley originally made to Buchanan:

It is understood that I am purchasing the . . property for the purpose of having erected thereon a house which I propose to make my residence, and . . . I shall not be required to accept a deed . . . or to pay for said property unless I have the right under the laws of the State of Kentucky and the City of Louisville to occupy said property as a residence.

Record at 2, Buchanan v. Warley, 245 U.S. 60 (1917). This language was also incorporated into the sales contract. It was obviously made with challenge to the statute in mind. Collusiveness is also suggested by the fact that Stuart Chevalier, a Louisville city attorney, represented defendant Warley from the onset of the case. Buchanan's original petition, filed December 1, 1914, was a simple breach of contract pleading which demanded that Warley pay what he owed. Warley's answer, filed January 11,1915 , raised the contractual language quoted above and the city ordinance as a defense. In short, neither the petition nor the answer hinted at a challenge to the statute-but because the answer itself was drafted by an attorney employed by the city as opposed to private counsel, it is clear that the parties agreed upon the true purpose of the lawsuit from the beginning. See Record at 1-5, Buchanan v. Warley, 245 U.S. 60 (1917).

191. See Harris v. City of Louisville, $165 \mathrm{Ky} .559,571,177$ S.W. 472, 477 (1915) (citing Berea College v. Commonwealth, 123 Ky. 209 (1906), aff'd, 211 U.S. 45 (1908)).

192. See Supplemental and Reply Brief for Defendant in Error on Rehearing at 123, Buchanan v. Warley, 245 U.S. 60 (1917).

193. Id.

194. Id. 
support of racial mixing. The Louisville attorneys argued that the surprise use of scientific data was all part of an NAACP conspiracy to foist racial mixing on America. The City of Louisville felt obliged to reply in kind. ${ }^{195}$

Chevalier and Beckley modeled their reply brief after Brandeis's famous brief in Muller v. Oregon. ${ }^{196}$ The brief cited Brandeis-appointed to the Court a year earlier by President Wilson-for the proposition that certain commonly-known facts could be brought to the Court's attention even though they had not been part of the fact findings at trial. ${ }^{197}$ Then the brief proceeded with a half-dozen pages of legal summation, followed by one hundred pages of social science data, designed to prove that amalgamation of the races was clearly not in the best interests of either blacks or whites. ${ }^{198}$

Many of the sources Chevalier and Beckley quoted were not social scientists at all. They included Henry W. Grady, editor of the Atlanta Constitution, Charles W. Eliot, former president of Harvard University, and Washington Gladden, a prominent liberal Protestant clergyman who was one of the leaders of the Social Gospel movement. ${ }^{199}$ These writers were quoted in the Louisville brief not because they had conducted any scientific studies, but rather because they revealed that America's intellectual leaders and even one of its outstanding social liberals were opposed to the mixing of races. Without distinguishing among its authorities, the Louisville brief also quoted some of the South's most notorious bigots-such as John Vertrees, ${ }^{200}$ who had argued in 1913 that the Civil War Amendments to the Constitution were part of an AfroAmerican plot to destroy the purity of the white race. ${ }^{201}$ Vertrees's work was not so much an attack on racial amalgamation as it was a rebuke of Congress for giving blacks the vote. He believed that white solidarity

195. See id. at $142-49$.

196. 208 U.S. 412 (1908). See supra note 15.

197. Chevalier and Beckley may have been solicitous to Brandeis for a reason: Moorfield Storey and Justice Brandeis were bitter political enemies. As prominent Boston attorneys the two had often opposed each other, and in 1916 Storey was one of the most ardent opponents of Brandeis's Supreme Court nomination. At a Senate subcommittee hearing on the nomination, Storey testified that in his opinion Brandeis was a brilliant lawyer but was "ruthless in the attainment of his objectives, not scrupulous in the methods he adopts and not to be trusted. . . . [T] dence in him among a representative class of men in the community in which I live . . . " A. MASON, BRANDEIS: A FREE MAN'S LIFE 481 (1946) (quoting nominating hearings); see also id. at 477-78 (discussing Storey's testimony criticizing Brandeis).

198. Supplemental and Reply Brief for Defendant in Error on Rehearing at 142-254, Buchanan v. Warley, 245 U.S. 60 (1917).

199. See id. at $158,162-63,181-82$.

200. See id. at 173-74 (quoting Vertrees, The Fifteenth Amendment and Blacks and Whites in the United States, 6 LAw. \& BANKER 129, 129-42 (1913)).

201. Vertrees, supra note 200 , at $129,137-42$. 
could be maintained only if the white race retained a monopoly on political power. ${ }^{202}$

The Louisville brief also cited many respectable scientific sources for the argument that the offspring of interracial marriages were physically and mentally inferior. Like Attorney General Breathitt in Berea College, Chevalier and Beckley relied heavily on William Benjamin Smith's The Color Line. ${ }^{203}$ Smith in turn had drawn much of his evidence of mulatto degeneracy from Benjamin A. Gould, who had been employed as actuary to the United States Sanitary Commission. Gould had been hired by the commission to perform several anthropometric studies of the autopsy reports of black and white Civil War soldiers. He had discovered that the average lung capacity of a white soldier was 185 cubic inches, and of a black soldier 164 cubic inches. However, the average capacity of the lungs of the mulatto was only 159 cubic inches. ${ }^{204}$ The result, according to Gould, was that mulattoes were chronically unhealthy and unfit for hard labor. Because their hearts and respiratory systems had to work harder to keep them alive, they died much younger than either blacks or whites. None were known to have lived beyond sixty years. ${ }^{205}$

The Louisville brief also relied on the work of Scottish geologist and natural historian James Bryce, who had visited America in order to observe its race problem. Bryce concluded that when "similar" races, such as Caucasians and Chinese, intermarry the resulting stock can be quite healthy-as strong and intelligent as either parent. When "remote" races intermarry, however, they are so biologically different that genetic defects are sure to result. ${ }^{206}$ Bryce viewed the American South as having the unusual problem that it was populated simultaneously by the highest and the lowest races of mankind. ${ }^{207}$ Any intermarriage between the two races could yield grossly inferior offspring.

The mere fact that the mulatto was inferior was not sufficient. Chevalier and Beckley also produced evidence that interracial marriage was on the rise. Alexander Harvey Shannon, chaplain of the Mississippi State Penitentiary and an ethnologist, had found that at the time of the

202. See id. However, the feeling that blacks should be denied the vote was certainly not unique to southern extremists. It even extended to rather sophisticated northern social scientists who believed that blacks were incapable of making informed political choices. See, e.g., $1 \mathrm{~J}$. BuRGESS, Political Science and Comparative Constitutional Law 35-39, 44-45 (1898) (members of Teutonic race are most capable of establishing and administering nation states to govern people of other races).

203. See supra note 74.

204. See B. Gould, Investigations in the Military and ANThropological Statistics OF AMERICAN SOLDIERS 471 (1869).

205. Id.

206. Bryce, Thoughts on the Negro Problem, 153 N. AM. REv. 641, 643-44, 647 (1891).

207. Id. at 649-51. 
Civil War mulattoes composed $13.2 \%$ of the black population. By 1890 , however, $15.2 \%$ of the black population was mulatto, and indications were that their number was still growing. ${ }^{208}$ The figures seemed to confirm Herbert Spencer's theory that intelligence and fertility were inversely related. ${ }^{209}$ If encouraged by state toleration, the mulattoes would breed uncontrolled until they overran the country. Shannon himself was alarmed by the increase and feared that the South might someday be crowded with morally and physically degenerate "sambos," like the offspring of blacks and Indians who populated parts of the Honduras. ${ }^{210}$ In Shannon's view, these people had lost their identity with any race; they had no culture and, as a result, no sense of social morality. Shannon concluded that "[t]hese figures are sufficient to warrant whatever discrimination may be found necessary in controlling the situation."211

In case the Supreme Court should think that this scientific justification of racism was a unique product of southern prejudice, Chevalier and Beckley also documented the existence of racial tension in the North. Racial prejudice, they found, had been growing in northern cities at an alarming rate since the Civil War. They relied on a rather remarkable study by Frank U. Quillin, a sociologist from Knox College in Illinois. ${ }^{212}$ In 1913 Quillin published a survey of racial prejudice in several Ohio cities. Quillin concluded that northern racial prejudice was much stronger in 1910 than it had been in 1865.213 Further, racial tensions seemed to grow as the proportion of blacks in an area increased; ${ }^{214}$ close contact seemed to intensify racial animosity. Quillin documented the rather surprising conclusion that blacks in Ohio were economically

208. A. Shannon, Racial Integrity and Other Features of the Negro Problem 22 (1907). Although Shannon's data about the increasing population of mulattoes may have been correct, they really proved nothing. They were a function of the prevailing definitions of "Negro,"-a legal term defined in some states as a person with as little as $1 / 8$ black blood and, in others, as little as 1/16 black blood-and of "mulatto," a popular term-and one used by Shannon-for anyone whose black blood was greater than $1 / 16$ but less than $15 / 16$. See J. Williamson, supra note 173, at 24. The legal definition of "Negro" and Shannon's definition of "mulatto" thus overlapped. As a result, if a person who was $50 \%$ black and $50 \%$ white married a "pure-blooded" black, the marriage was in every state a legal union of two Negroes, and the offspring were also considered black by the states. For purposes of Shannon's study, however, the offspring were considered mulatto. Even if the frequency of interracial marriage (i.e., marriage of a person with $1 / 16$ "black blood" or more with a person with no "black blood") after the War had declined, the relative percentage of mulattoes in the population could have increased under these definitions.

209. See M. HARRIS, supra note 63, at 127.

210. See A. Shannon, supra note 208, at 16-95.

211. Id. at 76.

212. See Supplemental and Reply Brief, supra note 200, at 182-98 (quoting F. Quillin, ThE Color Line in OHio: a History of Race Prejudice in a TYPical Northern State 1-11, $125-65$ (1913)).

213. See F. QUillin, supra note 212, at 2.

214. See id. at 1. 
worse off than blacks in the South; Ohio was much more heavily industrialized and unionized, but virtually every northern trade union excluded blacks from membership. ${ }^{215}$ Quillin concluded that in time northern racial attitudes would be no different from attitudes in the South, and then "the Negro problem" would take on national dimensions. ${ }^{216}$

The Supreme Court found the racial zoning statutes unconstitutional.217 Justice Day's opinion never acknowledged the pages of scientific evidence in the Louisville brief, ${ }^{218}$ and it completely sidestepped the policy arguments that both sides in the controversy had argued so strenuously. The Court based its decision on a rationale different froin that which the social science data were intended to suggest. It expressly refused to hold that racial zoning was invalidated by any special protection that the fourteenth amendment gave to blacks. ${ }^{219}$ Rather, Justice Day held for a unaninious Court that the constitutionally protected right to own property "includes the right to acquire, use, and dispose of it."220 This was a property case, not a race case, and Buchanan's right to sell his property to whonrever he pleased had been unconstitutionally abridged: "The right which the ordiniance annulled was the civil right of a white man to dispose of his property . . . to a person of color, and of a colored

215. Id. at 6-7, 125-66. Racial exclusion by labor unions should not be surprising. In general, competitive markets minimize discrimination, for the seller must sell to the buyer willing to pay the highest price, and the buyer in competition wants to buy at the lowest price, regardless of the race of the opposite party to the transaction. A seller who refuses to deal with blacks cuts himself off from part of his potential market and will not bc able to compete effectively against an equally efficient seller who deals with all buyers regardless of race. To the extent that labor unions-particularly in closed-shop states-acquire a monopoly in their market, they can afford to discriminate because they are not competing with nonunion laborers for jobs. Furthermore, members of labor unions have market power that enables thein to obtain higher wages for the same work than they would receive if all laborers competed against each other for wages. This premium attracts a great many prospective entrants-that is, many outsiders would like to join the union. At the same time, the higher wages reduce the demand for labor. Because of the resulting excess supply of labor, the union must have a way of excluding some applicants, and race discrimination is one way of doing so, particularly if union insiders believe the excluded minority group possesses a high proportion of a certain undesired characteristic, such as laziness or criminality. This may explain why race discrimination was so prevalent among labor unions in the early twentieth century. See R. POSNER, THE ECONOM1CS OF JUSTICE 353-54 (1981).

216. F. QUILLIN, supra note 212, at 1.

217. Buchanan v. Warley, 245 U.S. 60,82 (1917).

218. In fact, the Brandeis Briefs were almost universally ignored in Supreme Court opinions of the substantive due process era. Even the original Brandeis Brief was acknowledged by the Supreme Court in only one sentence and a footnote. See Muller v. Oregon, 208 U.S. 412, 419 \& n.1 (1908).

219. Buchanan v. Warley, 245 U.S. 60, $75-79$ (1917). But see A. BICKEL \& B. SCHMIDT, supra note 1, at 813-17, 819-20 (arguing that Buchanan was essentially a bit of liberalism that surfaced during World War I only to die during the Harding administration in the 1920's).

220. Buchanan v. Warley, 245 U.S. 60, 74 (1917). 
person to make such disposition to a white person."221

\section{Two Revolutions: Social Science and Constitutional RIGHTS}

The United States Supreme Court has received an extraordinary amount of criticism for its race decisions during the period 1896-1947. Much of that criticism is based on a myopic legal history. Although it did not use the fourteenth amendment to combat racial segregation in any comprehensive way until the 1940's, 222 the Court during this period was not dominated by uninformed and outmoded bigotry. To be sure, some members of the Court could be characterized that way. However, for most of the period the Court closely tracked prevailing scientific opinion on race. No responsible judge would have believed that the fourteenth amendment required the state to do something manifestly unreasonable or grossly injurious to the public health or welfare. Even today, for example, a temporary segregation of white and black inmates is probably lawful in times of racial tension, despite the strictures of the equal protection clause. ${ }^{223}$ Of course, we now have a verbal formulation that defines the limits of racial discrimination by the state: any racial classification must be justified by a "compelling state interest." 224 However, the determination of whether a compelling state interest exists in an area as complex as race relations can depend on the use of sophisticated social science. Brown v. Board of Education, ${ }^{225}$ after all, was a "social science" decision. Chief Justice Warren found his excuse, if not his reason, for condemning school segregation in a number of sociological and psychological studies-studies made by scientists who were thoroughly committed to environmentalism. 226

221. Id. at 81 . In 1926 the Supreme Court unanimously ruled that private restrictive covenants in deeds, by which persons agreed when they purchased property that they would not resell to blacks, raised no fourteenth amendment issues nor any other federal questions. For the following twenty years property developers and owners were therefore free to do by private agreement what states could not do by statute. See Corrigan v. Buckley, 271 U.S. 323, 330 (1926) (suit to enjoin conveyance of real estate dismissed for lack of jurisdiction), distinguished in Shelley v. Kraemer, 334 U.S. 1, 8-9, 13 (1948).

222. The development of the case law is described superbly in narrative form in R. KLUGER, supra note 1; see also C. BARNES, supra note 1 (describing cases involving segregated transportation facilities).

223. See Lee v. Washington, 390 U.S. 333, 334 (1968) (Black, Harlan, Stewart, JJ., concurring) (" $[\mathrm{P}]$ rison authorities have the right, acting in good faith and in particularized circumstances, to take into account racial tensions in maintaining security, discipline, and good order in prisons and jails.").

224. L. Tr1be, American Constitutional. LAW 1003 (1978).

225. 347 U.S. 483 (1954).

226. See id. at $494 \mathrm{n} .11$ (citing various social science sources). Much has been written about the effects of social science data on the Brown decision. See, e.g., P. RosEN, THE SUPREME COURT AND SOC1AL SC1ENCE (1972) (analysis of the sociological underpinnings of Brown); see also Clark, Deseg- 
Historians too easily write the history of the Supreme Court the way science historians once wrote the history of science; the history of science was the history of "wrong" theories. It is easy to assume that beginning with the Warren era the Supreme Court began studying and internalizing "correct" social science. Yet the history of science is more complex than that, and we cannot allow such a quick and easy explanation of the integration cases to pass. Science itself goes through rapid change, and a century from now today's science will be no more correct than the science of the Victorian Era is today. More importantly, however, we have come to believe that science reflects our cultural values as much as it determines them-that the sciences, the arts, religion, and history together compose a world view that changes as a piece. Science responds to what is in the air227_and in the 1950's and 1960's the air around American universities was filled with racial egalitarianism.

The racial attitudes of the Justices of the Progressive Era Supreme Court were necessarily a product of the times. To be sure, the Court operated under a set of formal rules that often forced it to ignore social science data. Nevertheless, the data were there, and were brought to the Court's attention. The Court considered them and accounted for them, even if it could not obviously derive its rationales from them. Attorney

regation: An Appraisal of the Evidence, 9 J. Soc. IssuES, Apr. 1953, at 1. Chief Justice Warren obviously relied heavily on a statement prepared by a group of sociologists, anthropologists, and psychologists when he prepared the opinion; it summarizes the same data that Warren cites. Compare The Effects of Segregation and the Consequences of Desegregation: A Social Science Statement, 37 MinN. L. Rev. 427, $429-38$ (1953) with Brown, 347 U.S. at 494. Kenneth B. Clark, a black sociologist, probably had more to do with Warren's use of social science data than any other social scientist. See, e.g., Brown, 347 U.S. at 494 n.11 (citing K. ClARK, EFFECT OF Prejudice AND Discrimination on Personality Development (1950)). However, one of Clark's former teachers, Henry E. Garrett, professor of psychology at Columbia University, was the chief expert for the other side, and one of the principal scientific supporters in the 1950's of segregated education. See I. Newby, Challenge to the Court: Social Scientists and the Defense of SegregaTION, 1954-1966, at 62, 76, 91-104, 122-23, 163 (1967) (describing Garrett as the "most distinguished social scientist who joined the racists").

227. For example, the inferences that Kenneth Clark drew from his famous "doll experiments," which impressed Earl Warren so much, were questionable: liberals could conclude one thing from the data and conservatives quite another. See C. PUTNaM, RACE AND REALITY: A SEARCH For Solutions $71-74$ (1967) (criticizing Clark's conclusions); van den Haag, Social Science Testimony in the Desegregation Cases-A Reply to Professor Kenneth Clark, 6 VILL. L. Rev. 69, 77 (1960) (same). In the last decades there has been a dramatic increase in the volume of scientific research into problems of race and IQ; much of this research challenges the current environmentalism and finds at least modest correlations between race and intelligence. Both the government and private foundations have been reluctant to fund such research, thus creating a conflict between the American ideals of equality on the one hand, and academic freedom on the other. These problems are thoroughly discussed in an excellent article by Delgado, Bradley, Burkenroad, Chavez, Doering, Larcliere, Reeves, Smith \& Windhausen, Can Science be Inopportune? Constitutional Validity of Governmental Restrictions on Race-IQ Research, 31 UCLA L. REV. 128, 128-44, 225 (1983) (concluding that regulation of genuinely scientific race-IQ research may be constitutional if carefully fashioned). 
General Breathitt, Stuart Chevalier, and Pendleton Beckley all tried to do what Brandeis had done in the Muller case: to convince the Court that the state legislature had a reasonable basis-confirmed by scientific data-for doing what it did, and that its actions did not conflict with some long-cherished moral principle.228 Within the scientific paradigm of the day, the costs that racial integration would impose on all of society (both white and black) far exceeded any value that American blacks might incidentally realize from being permitted to associate closely with the Caucasian.

Although the Progressive Era Court had not yet developed the "compelling state interest" analysis of equal protection cases, coinpelling interest arguments were precisely what was being considered. In 1900, and even in 1925, most American social scientists believed that interracial propagation was at best harmful and at worst disastrous for the future of white America. 229 The battle between environmentalists and hereditarians over racial characteristics placed American liberals in a difficult position. The effects of integrated education and interracial marriage would be irreversible. If the hereditarians were correct, a generation or two of unrestricted amalgamation could do broad and permanent harin to American society. In fact, it could cost America its place as a world leader-for only America among world powers had to hive with a race problem of such staggering proportions. On the other hand, if the environmentahists should eventually be proven correct, then society could always grant the black American the social equality he demanded-with apologies, of course, for any past damage done. Even for those who felt strongly about it, integration becaine soinething inore safely done later than now.

Seen in this perspective Buchanan v. Warley expresses a casualness toward race uncharacteristic of the period in which it was decided. The year 1917 was the high tide of scientific racial determinisin, a time when it was easy to show that local government had a compelling interest in inaintaining racial separation. Both Attorney General Breathitt in 1908, and Chevalier and Beckley in 1917, could have made better scientific cases than they did for racial separation. Most of the data they relied on were quite old, and better evidence was available. During the early 1900's, distinguished American social scientists, including such liberal reformers as sociologist Edward A. Ross, ${ }^{230}$ psychologist G. Stanley

228. See supra note 15 and accompanying text.

229. See supra notes 25-63 and accompanying text.

230. See Ross, The Causes of Race Superiority, 18 Annals AM. ACAD. Pol. \& Soc. ScI. 67, 67. 89 (1901) (arguing a middle road between egalitarian theories and theories viewing "actual differences" among races "as hereditary and fixed"). 
Hall, ${ }^{231}$ and economist John R. Commons, ${ }^{232}$ all argued in favor of the notions of genetic determinism and the inherent superiority of the white race. ${ }^{233}$

The arguments would grow even stronger. In 1918 Paul Popenoe, the editor of the Journal of Heredity, and Roswell Hill Johnson, a professor at the University of Pittsburgh, published an enormously influential textbook, Applied Eugenics. An analysis of inherited racial characteristics led the authors to conclude that the Afro-American had certain hereditary shortcomings that nade hin1 unable to compete with whites in modern society. Miscegenation was dangerous because these characteristics would then infiltrate the white race as well. ${ }^{234}$

Even more devastating were the results of the Army intelligence tests conducted during World War I. In 1917 Robert M. Yerkes, Harvard University psychologist and president of the American Psychological Association, began a program of massive testing of United States Army recruits. Yerkes and his staff gave more than two million tests and published a detailed analysis of 160,000 of them. The people who analyzed the results generally assumed that the tests measured innate imtelligence, and the tests confirmed what inost social scientists already

231. See Hall, The Negro in Africa and America, 12 Pedagogical Seminary 350, 350-68 (1905) (discussing differences between Caucasians and Africans).

232. J. COMMONS, RACES AND IMMigRANTS IN AMERICA 1-21 (1913) (race and heredity are beyond human control, but a common language can facilitate assimilation).

233. See T. Gossett, RACE: The History OF AN IDEA IN AMERICA 154-74 (1963) (discussing these social scientists, and race theory during the Progressive Era); Wish, Negro Education and the Progressive Movement, 49 J. Negro HIsT. 184, 184-200 (1964) (same). Franklin Henry Giddings, one of the country's most prominent sociologists, believed that blacks learned more slowly than whites, and that their presence in classrooms with whites would retard white development. F. GIDDINGS, THe PRINCIPLES OF SOCIOLOGY 328 (1896). Giddings's conclusions continued to be debated until the 1950's. See McGurk, A Scientist's Report on Race Differences, U.S. NEWS \& WORLD REP., Sept. 21, 1956, at 92, 92-96 (concluding that improvements in the social and economic status of blacks since 1918 have not changed blacks' inferior capacity for education); McGurk, Comparative Test Scores of Negro and White School Children in Richmond, Virginia, 34 J. Educ. PsYch. 473, 473-84 (1943) (reporting test score differences between blacks and whites and suggesting a separate standard for blacks); see also McGurk, Negro v. White Intelligence-an Answer, 29 HARv. Educ. REV. 54, 54-60 (1959) (defending the author's conclusions and methods in lis studies of black and white test scores); Does Race Really Make a Difference in Intelligence? U.S. NEWS \& WORLD REP., Oct. 26, 1956, at 74, 74-76 (reply to McGurk by 18 social scientists). In some circles this debate over the relationslip between race and intelligence is still not over. See A. JENSEN, BIAS IN MENTAL TESTING 61-123 (1980) (discussing the distribution of mental abihty). For a superb history of intelligence testing, arguing that the racial biases of the testmakers predetennined their racist conclusions, see S. Gould, supra note 24, at 146. But see Davis, Neo-Lysenkoism, IQ, and the Press, 73 PuB. INTEREST 41 (1983) (a critical review arguing that Gould overstates the case for environmentalism).

234. See P. Popenoe \& R. Johnson, Applied Eugenics 280-303 (1918); E. EAst \& D. Jones, Inbreeding and OUtbreeding: Their Genetic and Sociological Significance 245-65 (1919) (concluding that selective imbreeding could be beneficial, but that in all cases imbreeding of whites and blacks would be harmful). 
suspected. The average full-blooded black scored only $70 \%$ as high as the average white; the average three-quarters black, $81 \%$ as high; the average half black, $81.2 \%$; and the average quadroon, $99 \% .235$

To be sure, these were "white" tests-culturally biased in favor of the people who produced them. ${ }^{236}$ From 1920 to the present, psychologists have debated which elements of intelligence are hereditary and which are environmental. Nevertheless, within the biological paradigm of the 1920's, the test results seemed clear evidence of hereditary racial inferiority. ${ }^{237}$

At the same time, however, the social sciences were undergoing a transformation that eventually changed the scientific community's view of the black American. Even in 1905, when William Benjamin Smith published The Color Line, 238 a few dissenters were questioning the doctrime of hereditary racial inferiority. The most notable of these was anthropologist Franz Boas. By 1905 Boas was scoffing at the comparative method of physical anthropology that was so popular among the evolutionary hereditarians. Boas pointed out that Gilded Age anthropologists often defined the Caucasian as "superior" and then measured the inferiority of other races by the extent to which they deviated from the Cauca-

235. See Psychological Examining in the United States Army, 15 Memolrs NaT'L ACAD. SCl. 705-42 (R. Yerkes ed. 1921) (statistical analysis of the intelligence of blacks in the army); Yerkes, Testing the Human Mind, 131 ATL. MoNTHLY 358, 358-70 (1923) (discussing psychological testing in the army). But see S. GouLD, supra note 24, at 192-225 (a critique of results of Yerkes's experiments). In 1914 George Oscar Ferguson conducted similar intelligence tests on 269 white and 319 black children in segregated schools in Richmond. Ferguson concluded that a "full-blooded" black child scored $74 \%$ as high as a white child, a child $3 / 4$ black $78 \%$ as high, and a child $1 / 2$ black $81 \%$ as high. A quadroon's intelligence was $94 \%$ as high as the intelligence of a white student. See Ferguson, The Psychology of the Negro: An Experimental Study, 5 ARCHIVES OF PsYCHOLOGY 1, 84-122 (1916); see also Ferguson, The Mental Status of the American Negro, 12 Sc1. MoNTHLY 533 (1921).

236. See S. Gould, supra note 24 , at $192-225$.

237. For the debate over cultural bias and environinental factors in intelligence testing, see $A$. JENSEN, BIAS IN MENTAL TESTING 465-634 (1980) (discussing various sources of bias in testing); $O$. KLINEBERG, NEGRo INTELligenCE AND SELeCtIVE MigRation 1-62 (1935) (concluding that the superiority of northern blacks over southern blacks is the result of environinental factors); $O$. KIINEBERG, RACE DIFFERENCES 1-13 (1935) (criticizing subjective theories of racial differences); O. Klineberg, RACE AND Psychology 5-7 (1951) (discussing how social, cultural, and environinental factors may affect test performance); 2 R. OSBORNE \& F. MCGURK, THE TESTING OF NEGRO INTELLIGENCE 290-97 (1966) (concluding that intelligence tests show native differences between blacks and whites); Delgado, supra note 227, at 131-44 (presenting a history of the controversy over intelligence testing). Jensen, Osborne, and McGurk argue that blacks perform more poorly than whites even on unbiased tests, but Marvin Harris states what is undoubtedly the prevailing view: "[I]f Hottentot babies were to be substituted at birth for English babies, their average cultural performanee would not differ in any siguificant fashion from a control group, except in features that respond to enculturation processes." M. HARRIS, THE RISE OF ANTHROPOLOGICAL TheORY 132 (1968); see also R. LEwONTIN, S. ROSE, \& L. KAMIN, Not IN OUR GENES: BIOLOGY, IDEOLOGY, AND HUMAN NATURE 3-15 (1984) (a recent argument for the saine position).

238. W. SMITH, supra note 73. 
sian. In addition, Boas attacked the general notion that there were discrete races at all.239 The comparative method of Lewis Henry Mor$\operatorname{gan}^{240}$ and William Benjamin Smith ${ }^{241}$ was based on the assumption that each race had evolved independently, radiating out from a primitive life form like the spokes of a wheel; alternatively, as the followers of Samuel George Morton argued, ${ }^{242}$ the races were never genetically connected at all. Each race was thus in its own stage of the evolutionary process. In contrast, Boas argued that the human race had evolved as a single species. Its specific identity was the result of a long history of interracial sexual contact. Those who believed that the children of interracial marriages were hikely to be deformed were therefore talking nonsense. ${ }^{243}$

Boas's budding cultural relativism was so foreign to Smith that the latter could not even understand its vocabulary. How could Boas say that the cultural achievements of each race must be studied in their own context? Smith tried to answer Boas by doing exactly what evolutionary anthropologists had been doing all along. He cited one western cultural achievement after another to demonstrate that the Caucasian race was in fact superior. After all, was not the American language far superior to the African dialects? Was not Christianity superior to spiritism, and western science clearly superior to African myth? To Smith these questions did not even merit argument. ${ }^{244}$

Boas's revolution in anthropology was only one battle in the great war between hereditary and environmental determinists that dominated the science of the 1910's and 1920's. In 1918 Edward Byron Reuter, a sociologist from the University of Iowa, published The Mulatto in the United States. ${ }^{245}$ Reuter did not commit himself on the wisdom of interracial marriage, but he concluded that most of the mulatto's social problems were environmental and not hereditary. ${ }^{246}$ Because miscegenation was looked upon so unfavorably, only the lowest class of white males took black wives or mistresses, according to Reuter; likewise,

239. See Boas, Human Faculty as Determined by Race, 43 Proc. AM. A. FOR ADVANCEMENT ScI. 301 (1894); Boas, Some Recent Criticisms of Physical Anthropology, I AM. ANTHROPOLOGIST 98, 106 (1899) (individuals cannot be classified as belonging to a certain type). Other articles written by Boas throughout his career have been reprinted in F. BOAS, RACE, LANGUAGE AND CULTURE (1940). For a summary and analysis of Boas's work, see M. HARRIS, supra note 135, at 250-89.

240. See L. Morgan, supra note 163, at 3-45 (tracing the progress of man from savagery and barbarism to civilization).

241. See W. SMITH, supra note 73, at 3-28 (identifying the instincts and obligations of the Caucasian male).

242. See supra notes $50-51$ and accompanying text.

243. See supra note 239.

244. W. SMITH, supra note 73, at 111-57.

245. E. Reuter, The Mulatto in the United States (1918).

246. Id. at 375-76. 
respected black women usually tried to marry black males. The result was that the mulatto had many hereditary and environmental difficulties that were not race-linked at all, but were simply a function of the intelligence and status of his parents. The mulatto's plight was exacerbated because he was disowned by both races and regarded as a rootless, useless half-breed. Reuter concluded that mulattoes could be just as healthy and intelligent as either of their parents. Because of the mulattoes' unique position, Reuter believed that they were potentially useful in a racially mixed society because they might "be a connecting link which holds together . . . divergent racial and cultural elements." 247

The real beginning of the end of racist anthropology did not occur until the late 1920's. In 1928, Melville J. Herskovits, Franz Boas's most gifted student, published his first book on the Afro-American, The American Negro. ${ }^{248}$ It discredited many long-held scientific ideas about the physical and mental characteristics of the black American. For example, evolutionary anthropologists of the late nineteenth century had been fond of pointing out that the African had many facial features that resembled those of the lower primates-thick lips, broad nostrils, and wide hips. The social science of the early twentieth century had associated these features with the lower intelligence blacks were presumed to have. Herskovits found that although statistically blacks did in fact have thicker lips and broader nostrils than whites, there was no correlation between these features and intelligence. In fact, highly intelligent, college-educated black women exhibited these features just as prominently as did economically and socially disadvantaged black women from Harlem. ${ }^{249}$ Herskovits concluded that the real problem of the Afro-American was white values and stereotypes, not black features. White scientists had assumed much too easily that particular features common to blacks were evidence of inferiority. Recognizing that individuals of a particular racial group have unique characteristics is much different from making value judgments about racial superiority. ${ }^{250}$

Nevertheless, as long as both sides of the nature/nurture controversy were alive, white America was provided with a rather stark social choice. Environmentalism encouraged-even demanded-integration. If the only important difference between white and black Americans was

247. Id. at 320 .

248. M. Herskovirs, The American Negro (1928).

249. Id. at 41-48; see also M. Herskovits, THE ANTHRopometry of the AMERICAN Negro 234-80 (1930) (reporting the results of four years of research on the physical form of the American black).

250. See M. Herskovits, supra note 248, at 51-66; see also G. MYrdal, AN AMERICAN DIlemma: The Negro Problem and Modern Democracy 83-153 (1944) (analyzing Herskovits's work). 
that the latter had suffered from inadequate education, poor economic conditions, and an unstable social and cultural life, then the cure was necessary and obvious: blacks must be given precisely and in full measure every advantage that had accrued to whites. On the other hand, if black Americans were innately and permanently less intelligent, and could not share classrooms with white students without retarding white development, and if the mixing of blood would result in deformed offspring, then segregation was essential to America's continued vitality.

The development of a ruling environmentalist paradigm to explain racial differences in test performance, physical integrity, crimmal behavior, and economic status took forty years. Scientific racism did not begin to disappear from American universities until the 1940's-not until the publication of such consensus-creating documents as Gunnar Myrdal's An American Dilemma in 1944. ${ }^{251}$

As Myrdal's book itself indicated, America had a long tradition of placing a high value on equality and opportunity. ${ }^{252}$ The long history of racism in America, as terrible as it appears from today's perspective, does not refute the claim that Americans as a group have had an egalitarian commitment. Although the commitment was present, it could not be honored if the cost were too high, and within the scientific paradigm of the Victorian, Progressive, and New Deal Eras, the costs were simply too high. Within that paradigm racial discrimination was justifiable because-even though it injured thousands of American blacks-it was perceived to create social benefits that outweighed those losses. ${ }^{253}$ On the other hand, when environinentalist science began to undermine the premises of genetic determinism, the social values of segregation became less apparent, and competing egalitarian values weighed more heavily in the scales. The new science effectively transformed American ideas about the value of segregation and racial discrimination.

By 1948 the Supreme Court was ready to adopt the new view. In that year the Court in Shelley v. Kraemer declared that judicial enforcement of private, racially exclusive real property covenants amounted to unconstitutional state action in violation of the fourteenth amendment. ${ }^{254}$ In coming to that conclusion the Court was encouraged by the new environmentalist science. The petitioners' arguments relied heavily on the cultural relativists, particularly Herskovits and Myrdal. They attacked the notions that racial categories were permanent or objective, and that racial integration was harmful. As amicus curiae, the Congress

251. G. MYRDAL, supra note 250.

252. Id. at 3-25.

253. See supra notes 25-63 and accompanying text.

254. Shelley v. Kraemer, 334 U.S. 1, 20 (1948). 
of Industrial Organizations (CIO) argued that the races of mankind are nothing more than "creations of the investigator, and creations with regard to which all the creators are by no means in agreement."2ss However, these creations "have been converted through ignorance and prejudice into rigid structures." 256 The result was racism. Within the new environmentalist paradigm one thing was absolutely clear: "a court cannot permit itself to determine the rights and disabilities of individuals upon the basis of 'race.' "257 The CIO based its arguments on nearly a dozen social science sources, all of which had been published after 1940.258 Coming when it did, the final decision in Shelley v. Kraemer was nothing short of remarkable. In few areas of the law has the Court responded more quickly and decisively to a radical and controversial transformation in the social sciences.

255. Application for Leave to Filc Brief Amicus and Brief Amicus Curiae on Behalf of Congress of Industrial Organizations and Certain Affiliated Organizations at 20, Shelley v. Kraemer, 334 U.S. 1 (1948) (quoting R. Linton, THE STUDY OF MAN 39 (1936)).

256. Id. at 21 .

257. Id. at 22.

258. Id. at 20-22 nn.2-5; see also Brief of the United States as Amicus Curiae, Shelley v. Kraemer, 334 U.S. 1 (1948) (signed by Attorney General Tom C. Clark, also urging nonenforcement of the restrictive covenants). This brief contains a great deal of social science data, most of it describing the deteriorating condition of black urban housing. See, e.g., id. at 28-30 nn.8-11. The brief also demonstrates the extraordinarily heavy use of racially restrictive covenants, despite their relatively recent origin. Id. at 25-39.

Those defending the racial restrictions also used social science briefs, generally to argue that racially integrated neighborhoods had higher crime rates. See, e.g., Petition for Rehearing at 26.31, Barrows v. Jackson, 346 U.S. 249 (1953), reh'g denied, 346 U.S. 841 (1953).

The use of social science arguments in Shelley v. Kraemer, like its use in Brown six ycars later, extended the logic of the Brandeis Brief considerably. In fact, social science data were used in Shelley and Brown in order to convince the Court to act legislatively. Brandeis used social sciencc data in Muller simply to convince the Supreme Court that a state legislature had a reasonable basis for passing a particular statute. See supra note 15. The Court was not asked by Brandeis to consider whether the social science findings were correct, but merely whether a legislature could reasonably have responded to them by passing the legislation in question. The brief in Buchanan was used in the same way. See supra notes 192-220 and accompanying text. In Shelley y. Kraemer, however, there was no statute at issue, but only restrictive covenants of a general type that the common law had always recognized and enforced either as covenants running with the land or as equitable servitudes. See 334 U.S. 1, 4 (1948). The Court was in effect being asked to hold that a type of restrictive covenant, generally enforceable at common law or in equity, should not be enforced on public policy grounds, and that social science provided the policy.

The story of the restrictive covenant cases, as well as a discussion of the brief and records, is recounted in C. Vose, Caucasians ONLY: THE SupReme COURT, THE NAACP, AND THE RESTRICTIVE Covenant CASES 177-210 (1959). 